\title{
Water-Quality Assessment of Part of the \\ Upper Mississippi River Basin, Minnesota and \\ Wisconsin-Volatile Organic Compounds in \\ Surface and Ground Water, 1978-94
}

\section{U.S. Geological Survey}

Water-Resources Investigations Report 95-4216

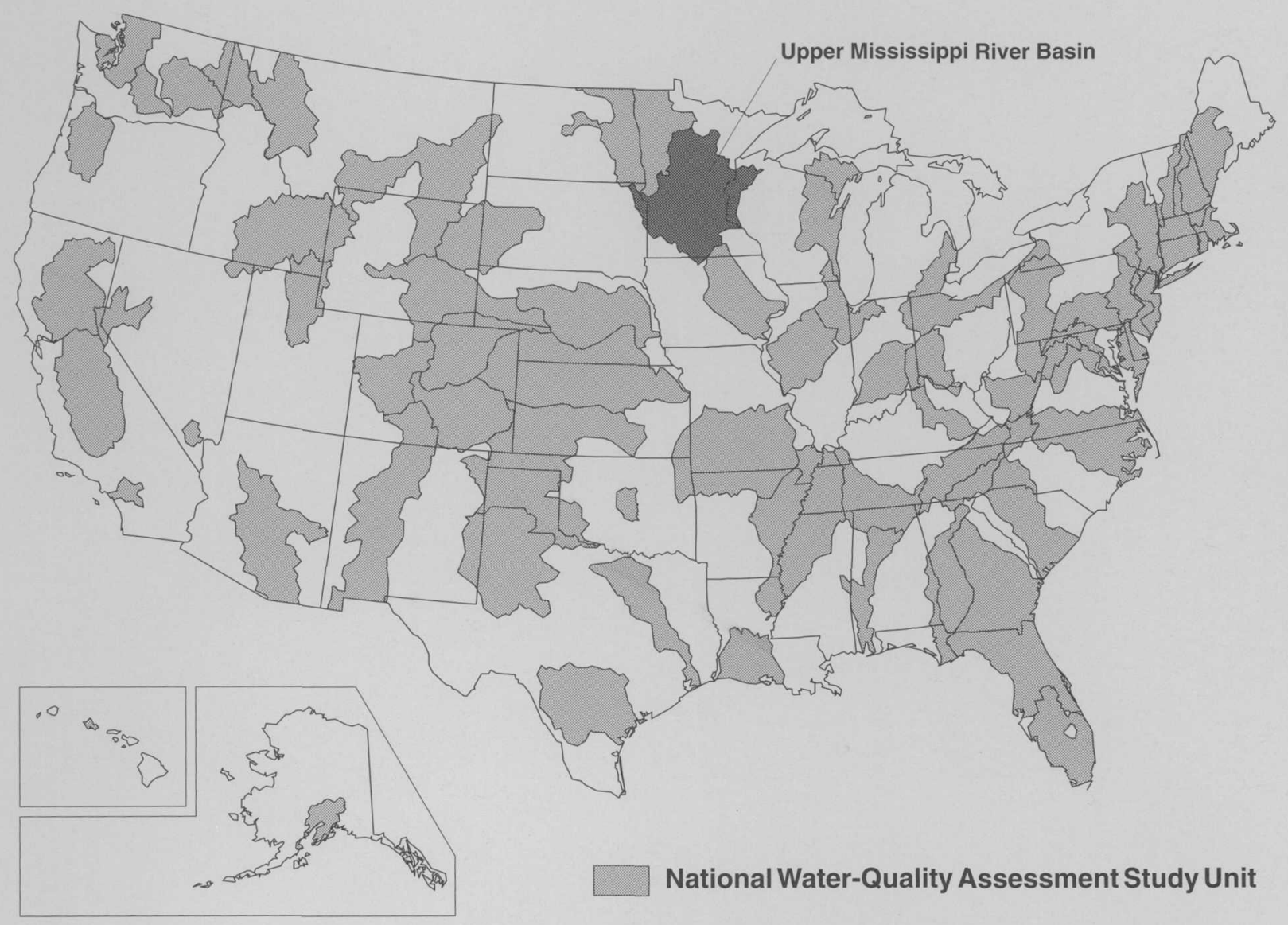

Contribution from the National Water Quality Assessment Program

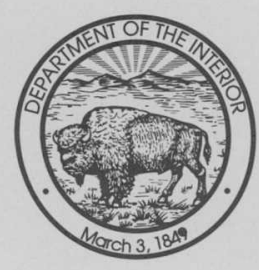


\&

६

? 


\section{Water-Quality Assessment of Part of the}

Upper Mississippi River Basin, Minnesota and

Wisconsin-Volatile Organic Compounds in

Surface and Ground Water, 1978-94

By William J. Andrews, James D. Fallon, and Sharon E. Kroening

U.S. Geological Survey

Water-Resources Investigations Report 95-4216

Contribution from the National

Water Quality Assessment Program

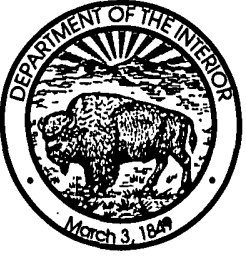




\section{U.S. DEPARTMENT OF THE INTERIOR \\ BRUCE BABBITT, Secretary \\ U.S. GEOLOGICAL SURVEY \\ Gordon P. Eaton, Director}

For additional information write to:

District Chief

U.S. Geological Survey

2280 Woodale Drive

Mounds View, MN 55112
Copies of this report can be purchased from:

U.S. Geological Survey

Earth Science Information Center

Open-File Reports Section

Box 25286, MS 517

Denver Federal Center

Denver, CO 80225 


\section{Foreword}

The mission of the U.S. Geological Survey (USGS) is to assess the quantity and quality of the earth resources of the Nation and to provide information that will assist resource managers and policy makers at Federal, State, and local levels in making sound decisions. Assessment of waterquality conditions and trends is an important part of this overall mission.

One of the greatest challenges faced by waterresource scientists is acquiring reliable information that will guide the use and protection of the Nation's water resources. That challenge is being addressed by Federal, State, interstate, and local water-resource agencies and by many academic institutions. These organizations are collecting water-quality data for a host of purposes that include: compliance with permits and water-supply standards; development of remediation plans for a specific contamination problem; operational decisions on industrial, wastewater, or water-supply facilities; and research on factors that affect water quality. An additional need for water-quality information is to provide a basis on which regional and national-level policy decisions can be based. Wise decisions must be based on sound information. As a society we need to know whether certain types of water-quality problems are isolated or ubiquitous, whether there are significant . differences in conditions among regions, whether the conditions are changing over time, and why these conditions change from place to place and over time. The information can be used to help determine the efficacy of existing water-quality policies and to help analysts determine the need for and likely consequences of new policies.

To address these needs, the Congress appropriated funds in 1986 for the USGS to begin a pilot program in seven project areas to develop and refine the National Water-Quality Assessment (NAWQA) Program. In 1991, the USGS began full implementation of the program. The NAWQA Program builds upon an existing base of water-quality studies of the USGS, as well as those of other Federal, State, and local agencies. The objectives of the NAWQA Program are to:
- Describe current water-quality conditions for a large part of the Nation's freshwater streams, rivers, and aquifers.

- Describe how water quality is changing over time.

- Improve understanding of the primary natural and human factors that affect water-quality conditions.

This information will help support the development and evaluation of management, regulatory, and monitoring decisions by other Federal, State, and local agencies to protect, use, and enhance water resources.

The goals of the NAWQA Program are being achieved through ongoing and proposed investigations of 60 of the Nation's most.important river basins and aquifer systems, which are referred to as study units. These study units are distributed throughout the Nation and cover a diversity of hydrogeologic settings. More than two-thirds of the Nation's freshwater use occurs within the 60 study units and more than two-thirds of the people served by public water-supply systems live within their boundaries.

National synthesis of data analysis, based on aggregation of comparable information obtained from the study units, is a major component of the program. This effort focuses on selected water-quality topics using nationally consistent information. Comparative studies will explain differences and similarities in observed water-quality conditions among study areas and will identify changes and trends and their causes. The first topics addressed by the national synthesis are pesticides, nutrients, volatile organic compounds, and aquatic biology. Discussions on these and other water-quality topics will be published in periodic summaries of the quality of the Nation's ground and surface water as the information becomes available.

This report is an element of the comprehensive body of information developed as part of the NAWQA Program. The program depends heavily on the advice, cooperation, and information from many Federal, State, interstate, Tribal, and local agencies and the public. The assistance and suggestions of all are greatly appreciated.

Robert M. Hirsch Chief Hydrologist 



\section{Contents}

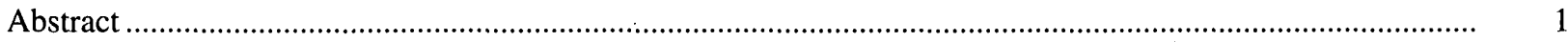

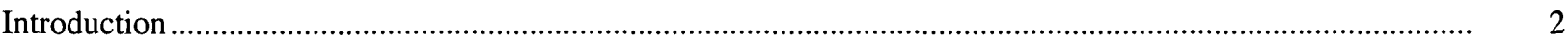

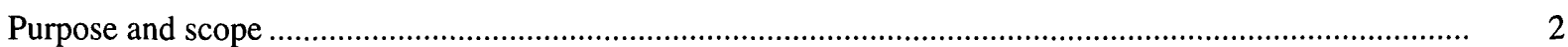

Environmental setting of study area ................................................................................................. 7

Sources and uses of volatile organic compounds and their potential effects on

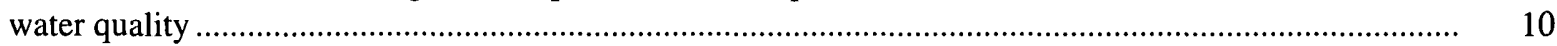

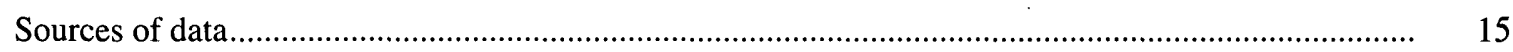

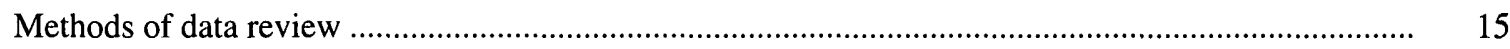

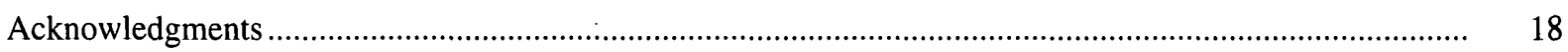

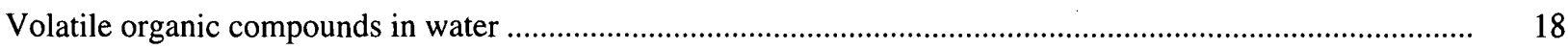

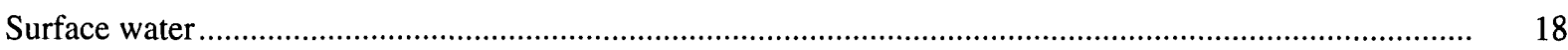

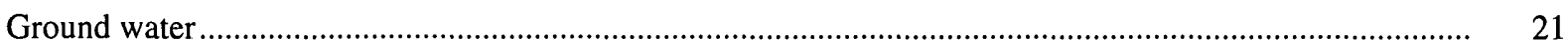

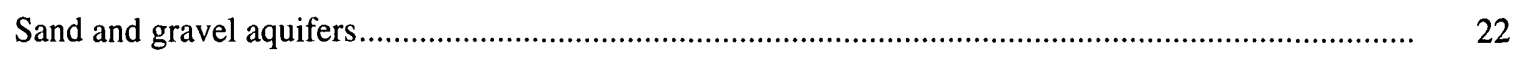

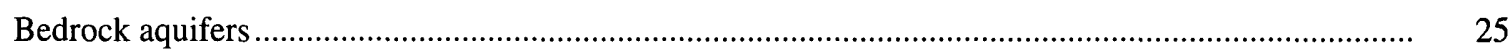

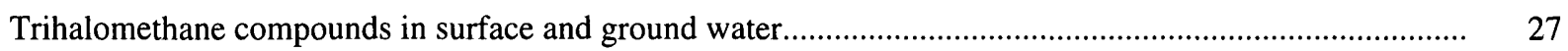

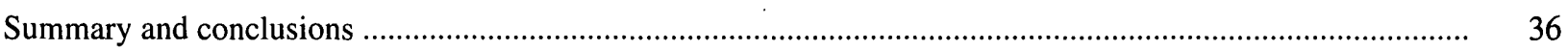

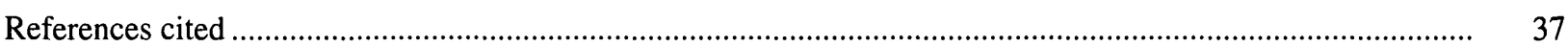

\section{Illustrations}

Figure 1-9. Maps showing:

1. Location of the study area in the Upper Mississippi River Basin National WaterQuality Assessment (NAWQA) study unit .................................................................... 3

2. Land cover in the study area ............................................................................................... 8

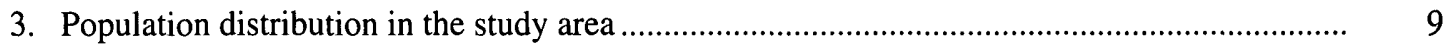

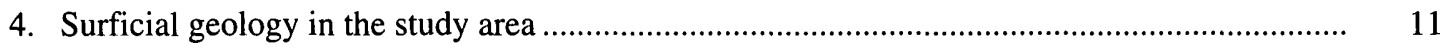

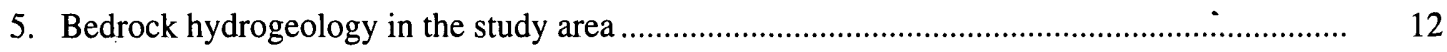

6. Locations of landfills and historical open dumps and locations of major registered sites discharging volatile organic compounds to streams in the study area

7a. Locations and quantities of releases of volatile organic compounds to water and land in the study area, 1992

7b. Locations and quantities of releases of volatile organic compounds to air in the study area, 1992

8. Surface-water sites sampled by Metropolitan Council Environmental Services (MCES), the Minnesota Department of Health, and the City of Minneapolis for volatile organic compounds in the study area, October 1982-August 1992

9. Locations of sampled wells and locations of wells with detections of target volatile organic compounds for sand and gravel aquifers in the study area 


\section{Illustrations-continued}

10. Bar chart showing percentages of detection of target volatile organic compounds and percentages of samples with concentrations exceeding Maximum Contaminant Levels for those compounds in water samples from wells completed in sand and gravel aquifers sampled by the Minnesota Department of Health, the Minnesota Pollution Control Agency, the U.S. Geological Survey, and the Wisconsin Department of Natural Resources in the study area.

11. Boxplot of the relations between well depths and target volatile organic compound detections in water samples collected by the Minnesota Department of Health, the Minnesota Pollution Control Agency, the U.S. Geological Survey, and the Wisconsin Department of Natural Resources from sand and gravel and bedrock aquifers in the study area.

12. Map showing locations of sampled wells and locations of wells with detections of target volatile organic compounds for bedrock aquifers in the study area

13-14. Bar charts showing:

13. Percentages of detection of target volatile organic compounds and percentages of samples with concentrations exceeding Maximum Contaminant Levels for those compounds in water samples from wells completed in bedrock aquifers sampled by the Minnesota Department of Health, the Minnesota Pollution Control Agency, the U.S. Geological Survey, and the Wisconsin Department of Natural Resources in the study area

14. Percentages of detection of analyzed trihalomethane compounds in water from surfacewater sites sampled by the Minnesota Department of Health, and the Metropolitan Council Environmental Services in the study area

15-16. Maps showing:

15. Locations of sampled wells and locations of wells with detections of trihalomethane compounds for sand and gravel aquifers in the study area.

16. Locations of sampled wells and locations of wells with detections of trihalomethane compounds for bedrock aquifers in the study area

17-18. Bar charts showing:

17. Percentages of detection of analyzed trihalomethane compounds in water from wells completed in sand and gravel aquifers sampled by the Minnesota Department of Health, the Minnesota Pollution Control Agency, the U.S. Geological Survey, and the Wisconsin Department of Natural Resources in the study area.

18. Percentages of detection of analyzed trihalomethane compounds in water from wells completed in bedrock aquifers sampled by the Minnesota Department of Health, the Minnesota Pollution Control Agency, the U.S. Geological Survey, and the Wisconsin Department of Natural Resources in the study area..... 


\section{Tables}

Table 1. Regulatory limits and uses of selected volatile organic compounds ..............................................

2. Sources of regional volatile organic compound data in the study area ......................................... 17

3. Summary of volatile organic compound concentrations in samples collected from 16 surface-water stations sampled by the Metropolitan Council Environmental

Services in the study area, Minnesota

4. Target volatile organic compounds detected by the Minnesota Department of Health in finished water supplies derived from surface water in the study area, Minnesota

5. Summary of volatile organic compound concentrations in samples collected from 8 stormwater-runoff stations sampled for the City of Minneapolis, Minnesota.

6. Frequencies of detection, numbers of wells sampled, concentration ranges, and median concentrations of target volatile organic compounds in ground-water samples analyzed by the Minnesota Department of Health, Minnesota Pollution Control Agency, U.S. Geological Survey, and the Wisconsin Department of Natural Resources in the study area, Minnesota and Wisconsin

\section{Conversion Factors and Abbreviations}

Multiply

inch (in.)

foot (ft)

square mile $\left(\mathrm{mi}^{2}\right)$

cubic foot per second $\left(\mathrm{ft}^{3} / \mathrm{s}\right)$
By

25.4

.3048

.02832
To obtain

millimeter

meter

square kilometer

cubic meter per second

Chemical concentrations: Chemical concentrations of substances in water are given in metric units of micrograms per liter $(\mu \mathrm{g} / \mathrm{L})$. Micrograms per liter is a unit expressing the concentration of chemical constituents in solution as mass (micrograms) of solute per unit volume (liter) of water. One thousand micrograms per liter is equivalent to one milligram per liter.

RCRA-Resource Conservation and Recovery Act

CERCLA-Comprehensive Environmental Remediation and Compensation and Liability Act 
、 


\title{
Water-Quality Assessment of Part of the Upper Mississippi River Basin, Minnesota and Wisconsin-Volatile Organic Compounds in Surface and Ground Water, 1978-94
}

\author{
By William J. Andrews, James D. Fallon, and Sharon E. Kroening
}

\begin{abstract}
The U.S. Geological Survey compiled and summarized analyses of volatile organic compounds (VOC's) in surface and ground water from water-quality data bases maintained by.Federal, State, and local agencies as part of a retrospective analysis of water-quality data for the Upper Mississippi River Basin study unit of the National WaterQuality Assessment Program. The retrospective analysis focused on a study area that encompasses $19,500 \mathrm{mi}^{2}$ of the eastern portion of the study unit. Major river basins in the study area include the part of the Upper Mississippi River drainage from Lake Pepin upstream to sampling stations on the Mississippi and Minnesota Rivers where long-term water-quality data are available and the entire drainage basin of the St. Croix River. The Twin Cities metropolitan area, with a population of 2.4 million people, is located in the south-central part of the study area. Water-quality data collected in the study area from 1978 through 1994 by the U.S. Geological Survey, the Minnesota Department of Health, the Minnesota Pollution Control Agency, the Wisconsin Department of Natural Resources, the Metropolitan Council Environmental Services, and the city of Minneapolis were included in the retrospective analysis.
\end{abstract}

In this report, assessment of the presence and distribution of VOC's in surface and ground water in the study area is restricted to two groups of VOC's: target VOC's, and trihalomethane compounds (THM's). Target VOC's, the most commonly detected non-trihalomethane VOC's in surface and ground water in the study area, include 1,1dichloroethane, 1,2-dichloroethane, 1,1,1-trichloroethane, trichloroethene, tetrachloroethene, benzene, ethylbenzene, toluene, meta+para-xylene, and ortho-xylene. Trihalomethane compounds described in this report include chloroform, bromodichloromethane, chlorodibromomethane, bromoform, and fluorodichloromethane.

Examination of water-quality data from widely distributed sampling networks of river sites and wells in the study area led to the following conclusions: 1) trace amounts of chlorinated VOC's were detected sporadically in waters of the Mississippi, Minnesota, St. Croix, and Vermillion Rivers; 2) benzene, ethylbenzene, toluene, and meta+paraxylene were detected sporadically in waters sampled from the chain of lakes used as the municipal supply for St. Paul, Minnesota; 3) the target VOC's were detected in less than five percent of ground-water samples at relatively low concentrations, generally near detection limits which ranged from 1 to 5 micrograms per liter; 4) VOC's were generally detected at similar frequencies, but at higher concentrations, in water samples from wells completed in sand and gravel aquifers than in water samples from wells completed in bedrock aquifers; 5) VOC's were most commonly detected in ground water in the vicinity of identifiable emission sites of VOC's, such as landfills, dumps, or major industries; 6) trichloroethene, a commonly used degreasing agent in dry cleaning, metal cleaning and cleaning septic lines, was the most frequently detected target VOC in ground water sampled from wells completed in both sand and gravel and bedrock aquifers; 7) wells producing water with detectable concentrations of the target VOC's tended to be shallower than wells producing water with no detectable concentrations of those compounds, but the differences in well depths were not statistically significant at a 95 percent confidence level; and 8) chlorination of water substantially increased the frequency of detection of trihalomethane compounds. The low frequencies of detection of the target VOC's and THM's in surface and ground water sampled from widely distributed sampling networks in the study area indicate that, although there are thousands of sites which can potentially emit these compounds to water, soil, and the atmosphere, these compounds have not had a widespread measurable effect on the quality of surface and ground water in the study area. 


\section{Introduction}

In 1991, the U.S. Geological Survey (USGS) began implementation of the National Water-Quality Assessment (NAWQA) Program. Long-term goals of the NAWQA Program are to describe the status of, and trends in the quality of large representative parts of the Nation's surface- and ground-water resources, and to identify the major natural and human factors that affect the quality of these resources. To meet these goals, nationally consistent data are being collected and analyzed. Because assessment of the water quality in the entire Nation is impractical, major activities of the NAWQA Program take place within a set of hydrologic systems called study units. Study units comprise diverse hydrologic systems of river basins, aquifer systems, or both.

The Upper Mississippi River Basin study unit, which encompasses an area of about $47,000 \mathrm{mi}^{2}$, includes the entire drainage area of the Upper Mississippi River Basin upstream of Lake Pepin (fig. 1). The study unit includes areas of rich agricultural lands, forests, wetlands, prairies, and a major urban area. Water quality of the Upper Mississippi River, which contains the headwaters of the largest river system in the Nation, is of concern due to reliance on surface water by major municipalities in the basin and due to the necessity of good quality water to maintain the health of regional aquatic ecosystems. Smaller municipalities and domestic water systems in the study unit rely on ground water is the their principal source of potable water. Ground water in unconfined sand and gravel aquifers of glacial and alluvial origins is particularly susceptible to degradation from anthropogenic activities at the land surface. Ground water in these sand and gravel aquifers and in adjoining bedrock aquifers is typically hydraulically connected to rivers throughout the study unit. The northern location of the study unit and potential interaction of surface and ground water are essential physical features necessary for a comprehensive national assessment of water quality.

Because the first phase of the NAWQA Program in this study unit, lasting from 1994-99, is focused principally on the effects of the seven-county Twin Cities metropolitan area (TCMA) on water quality and aquatic ecosystems in the study unit, the retrospective analyses and data collection for this phase of the program is focused primarily on a smaller study area, encompassing $19,500 \mathrm{mi}^{2}$ of the eastern portion of the study unit (fig. 1). The study area includes the part of the Upper Mississippi River Basin from Lake Pepin upstream to sampling stations on the Mississippi and Minnesota Rivers where long-term water-quality data are available, and the entire drainage basin of the St. Croix River. Most of the TCMA, with a population of 2.4 million people, is included in the south-central part of the study area (fig. 1).

Contamination by volatile organic compounds (VOC's) is one of the potential water-quality problems in the study area, particularly in the TCMA. VOC's are an empirically defined class of chemical compounds that include hydrocarbons (aliphatic and aromatic), halocarbons, aldèhydes, ketones, alcohols, carbon-based acids, and methyl-sulfur compounds. These compounds are generally synthetic chemicals used by industry or are components of hydrocarbon fuels. VOC's in water are of national concern because exposure to certain VOC's has been linked to human health concerns including damage to the liver, kidney, and circulatory and nervous systems. In addition, many VOC's are known or suspected human carcinogens. Because of their toxicity and potential carcinogenicity, VOC's are a major focus of Federal and State regulations designed to protect human and. ecosystem health. Contamination of ground and surface water by VOC's is of particular concern in urban areas and in watersheds with concentrated industrial activities because of the large numbers of possible emission sites in those areas.

In this report, assessment of the presence and distribution of VOC's in surface and ground water in the study area is restricted to two groups of VOC's: target VOC's and trihalomethane compounds (THM's). Target VOC's, the most commonly detected non-trihalomethane VOC's in surface and ground water in the study area, include 1,1-dichloroethane, 1,2-dichloroethane, 1,1,1trichloroethane, trichloroethene, tetrachloroethene, benzene, ethylbenzene, toluene, meta+para-xylene, and ortho-xylene. THM's described in this report include the VOC's chloroform, bromodichloromethane, chlorodibromomethane, bromoform, and fluorodichloromethane. Table 1 lists the regulatory limits (when established) of the target VOC's and the analyzed THM's and the major uses and sources of those compounds.

\section{Purpose and Scope}

The purposes of this report are to describe detections of selected VOC's in surface and ground water samples collected from widely distributed networks of sampling stations and wells, and to describe possible relations between the detection of these compounds in surface and ground water with human and natural factors in the study area. Water-quality data from monitoring wells at disposal and spill sites (point sources) of VOC's are discussed but not combined with water-quality data from widely distributed sampling networks in this report, because localized high levels of VOC 


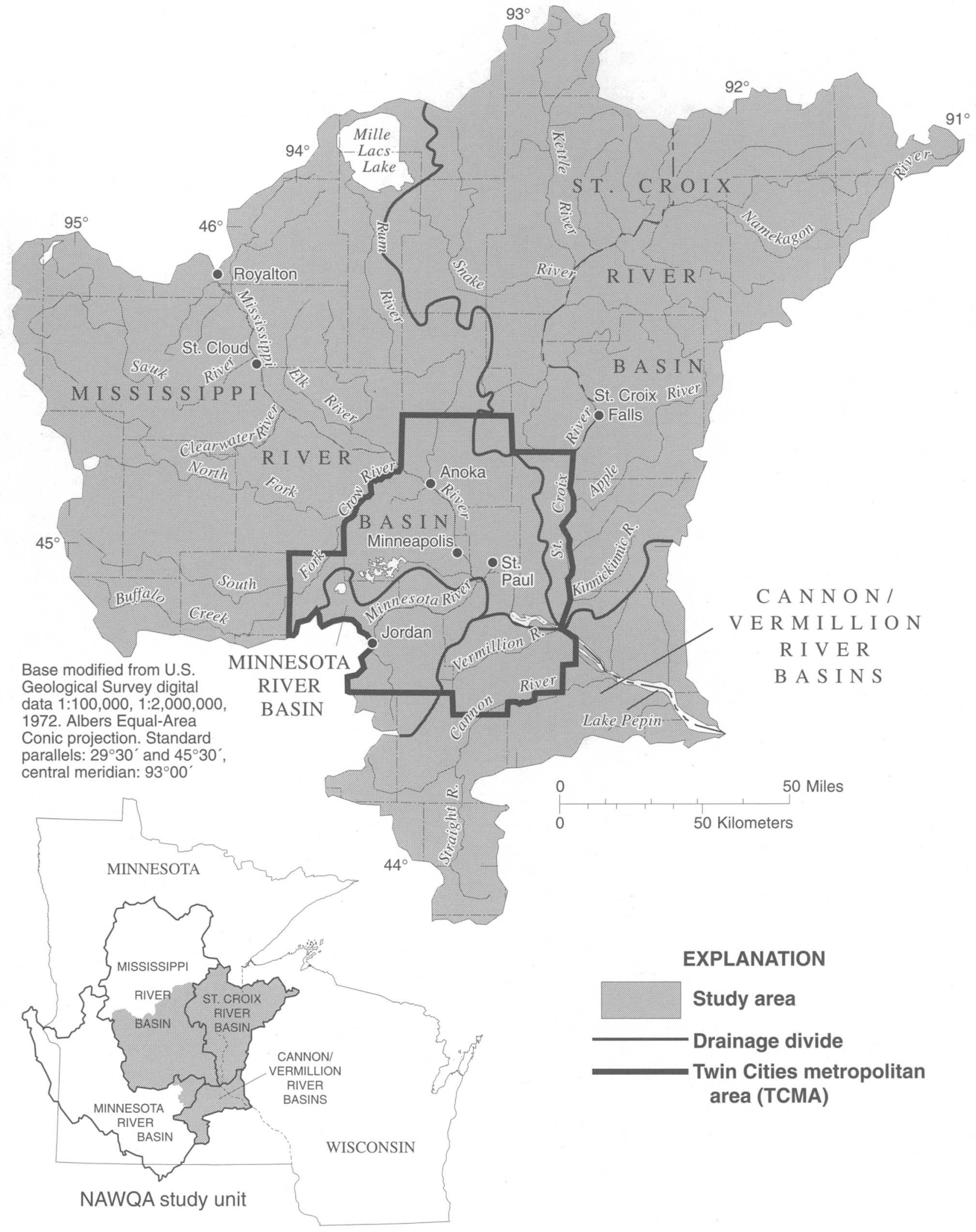

Figure 1.--Location of the study area in the Upper Mississippi River Basin National Water-Quality Assessment (NAWQA) study unit. 


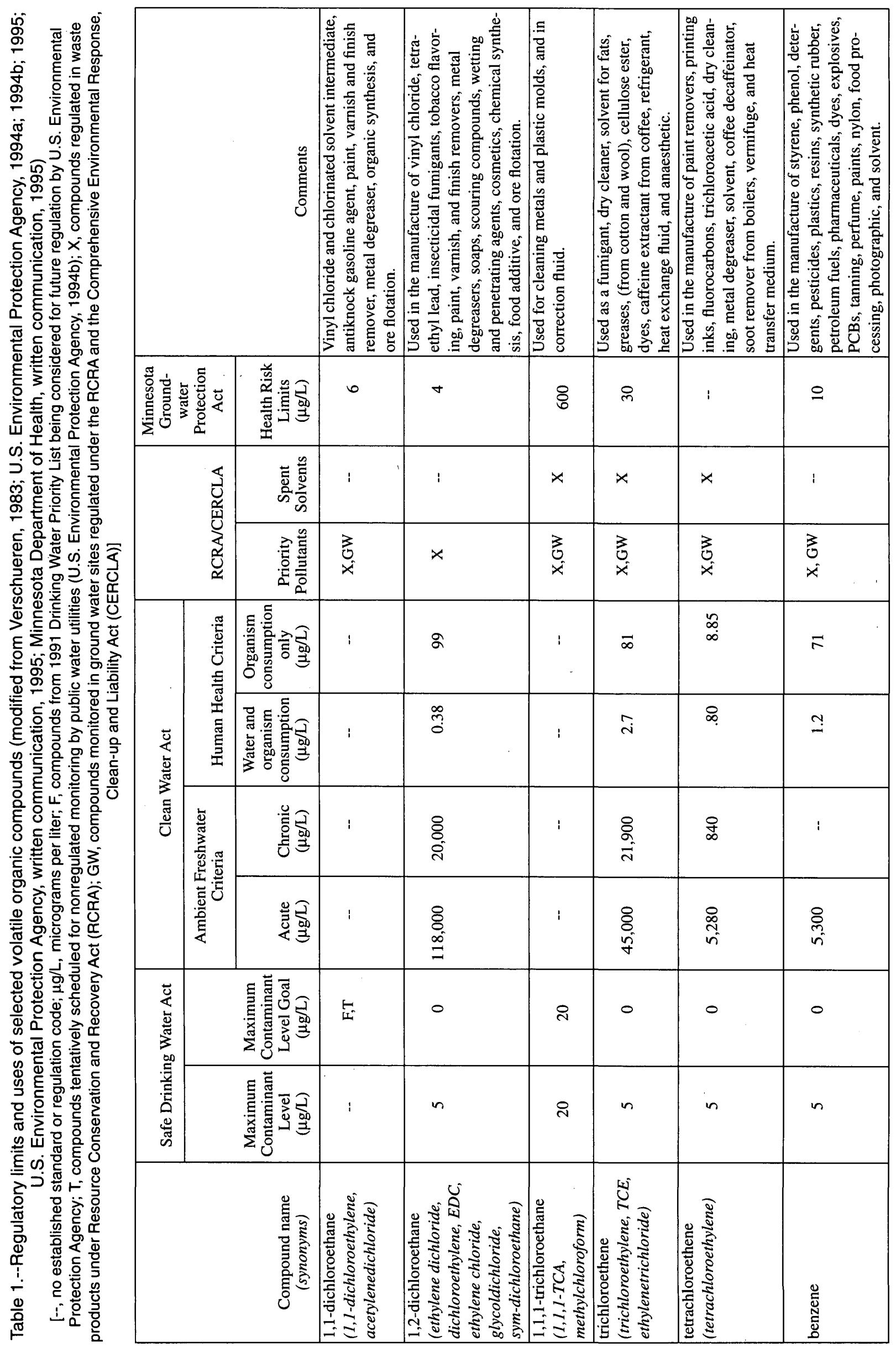




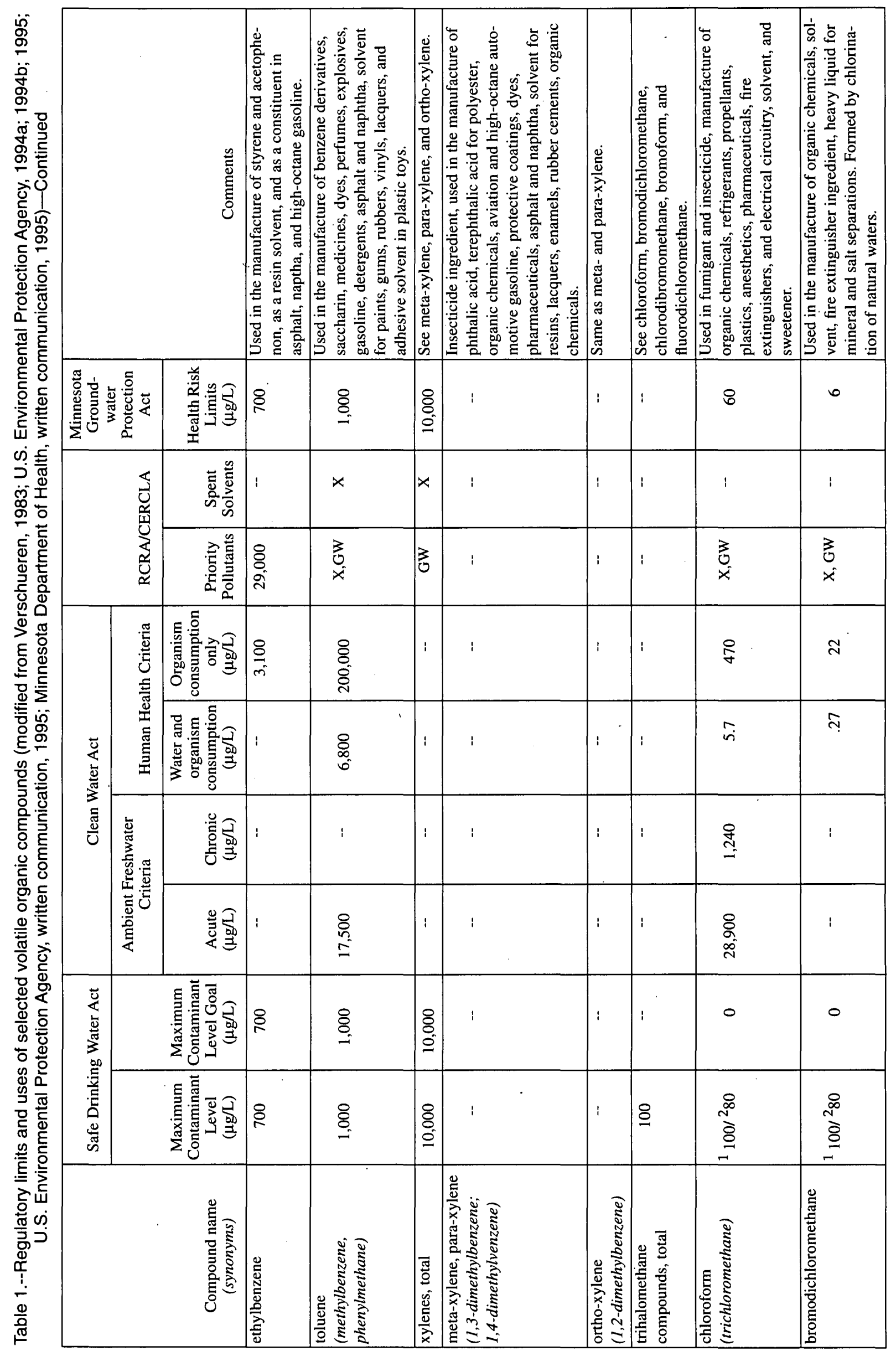




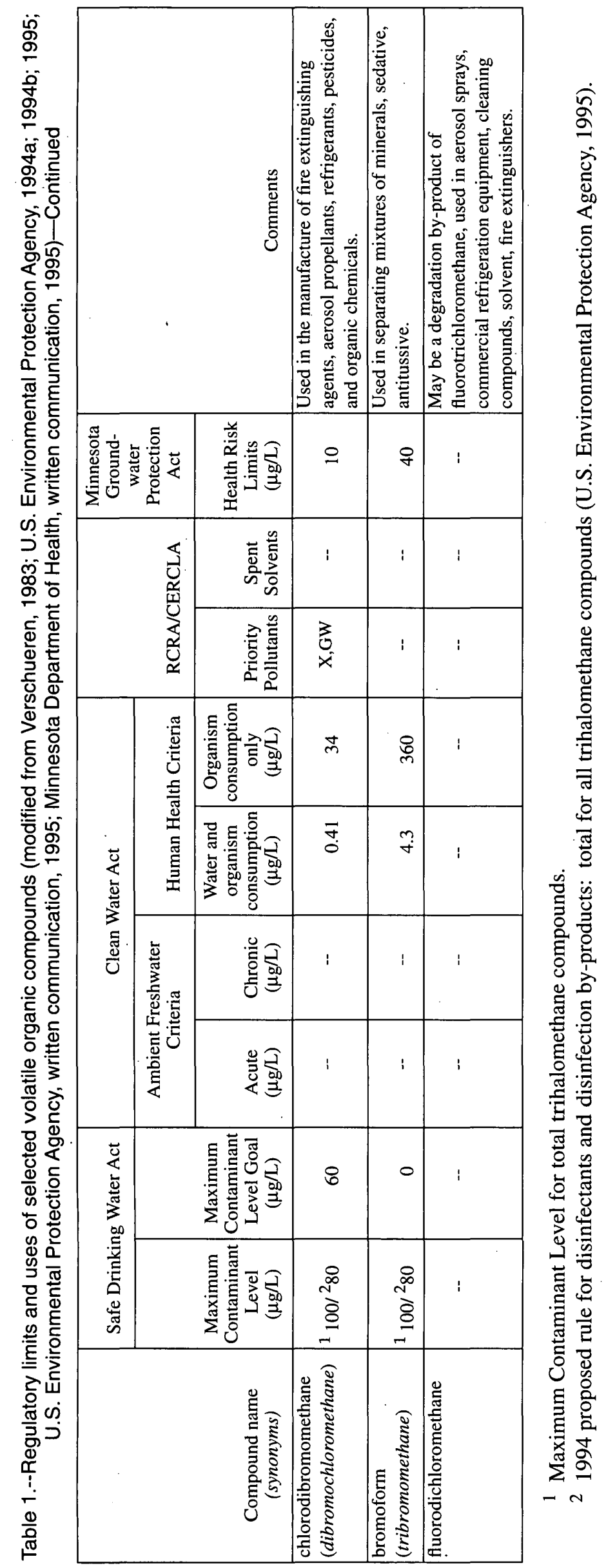


contamination of ground water at those sites has been well characterized and the focus of this report is to summarize typical water quality across the study area. Inclusion of water-quality data from numerous wells specifically sited to intercept contaminant plumes at those sites would positively skew data sets and would overemphasize relatively localized contamination of ground water by high concentrations of VOC's.

This report summarizes analyses of target VOC's and THM's in water samples collected in the study area by the U.S. Geological Survey (USGS), the Minnesota Department of Health (MDH), the Minnesota Pollution Control Agency (MPCA), the Wisconsin Department of Natural Resources (WDNR), Metropolitan Council Environmental Services (MCES, formerly known as Metropolitan Council Wastewater Services and Metropolitan Waste Control Commission), and the city of Minneapolis from 1978 through 1994.

\section{Environmental Setting of Study Area}

Major components of the environmental setting of the study area which can affect the presence of VOC's in surface and ground water include: climate, land cover, soils, population, water use, surface-water hydrology, and the hydrogeology of surficial sand and gravel aquifers and of bedrock aquifers.

The climate of the study area is subhumid. The average monthly temperature ranges from $11^{\circ}$ Fahrenheit $\left(-12^{\circ}\right.$ Celsius) in January to $74^{\circ}$ Fahrenheit ( $23^{\circ}$ Celsius) in July (Baker and others, 1985). Average annual precipitation increases from about 26 inches $(0.66 \mathrm{~m})$ in the western part to 32 inches $(0.81 \mathrm{~m})$ in the eastern part of the study area. About three-fourths of the annual precipitation falls from May through September (Baker and others, 1979). The majority of VOC's reaching surface and ground water may be due to runoff and infiltration of precipitation from the land surface. Relatively small percentages of VOC's in the atmosphere, usually less than one percent (depending on the Henry's law constant of the VOC), precipitate from the atmosphere as rainfall (J. Pankow, Oregon Graduate Institute, oral commun., 1995). VOC's can also diffuse directly from the atmosphere into surface water, the vadose zone, and ground water.

Land cover is probably the most critical component of environmental setting that can affect the presence of VOC's in the hydrosphere. VOC's are most likely to be emitted to the atmosphere and discharged to water in urban areas, where industrial and commercial emitters and transportation corridors are most concentrated. Areas with agricultural land cover would be expected to have less concentrated emissions, and forested areas would be expected to have the least concentrated emissions of VOC's. Using the land-cover classification system of Anderson and others (1976) agriculture was determined to be the dominant land cover in the western part of the study area, overlying about 60 percent of the area (fig. 2). Corn, soybeans, and hay are the principal crops grown in agricultural portions of the study area. Mixed deciduous and coniferous forests cover 23 percent of the study area, primarily in the northeastern portion of the area. Urban (including suburban) land covers are located primarily in the TCMA and occupy over 5 percent of the study area. Open water and wetlands cover 5 and 7 percent of the study area, respectively. The greatest concentration of the human population in the study unit, which is where VOC's are most likely to be emitted to the hydrosphere, is in the TCMA (fig. 3). The estimated population of the study area in 1994 was about $3,200,000$ people, $2,400,000$ of whom live in the seven-county TCMA (Missouri State Census Data Center, U.S. Bureau of the Census data, electronic commun., 1995).

Because of their volatile nature, VOC's are not likely to be detectable in surface water, except immediately downstream from points of VOC discharges to rivers and streams. Detection of VOC's in surface water are also affected by factors such as air temperature, water temperature, and the flow in receiving streams. Flow in the Upper Mississippi River, as defined in this report, is derived from three major confluent streams--the Mississippi, Minnesota, and St. Croix Rivers (fig. 1). Average flow of the Mississippi River, 10 miles upstream from Minneapolis, near Anoka, Minnesota, is $7,900 \mathrm{ft}^{3} / \mathrm{s}$. The average flow of the Minnesota River at Jordan, Minnesota (39.4 miles from its confluence with the Mississippi River) is $3,760 \mathrm{ft}^{3} / \mathrm{s}$. Average flow of the St. Croix River at St. Croix Falls, Wisconsin (52 miles upstream from its confluence with the Mississippi River at Prescott, WI) is $4,300 \mathrm{ft}^{3} / \mathrm{s}$. In addition to pointsource discharges of VOC's, runoff from urban areas may be an important source of VOC's to surface water. Runoff in the region varies spatially and annually, with most of the annual runoff occurring in spring and early summer from rains falling on saturated soils.

The presence and concentrations of VOC's in surface and ground water may be strongly affected by the permeabilities and chemical compositions of surficial deposits and soils formed on those deposits. The study area is mantled with a nearly continuous veneer of up to $100 \mathrm{ft}$ of unconsolidated deposits on bedrock uplands and up to $600 \mathrm{ft}$ of deposits in bedrock valleys and as terminal moraines. Those unconsolidated materials, which were deposited during advances and retreats of continental glaciers during the Pleistocene Epoch, 


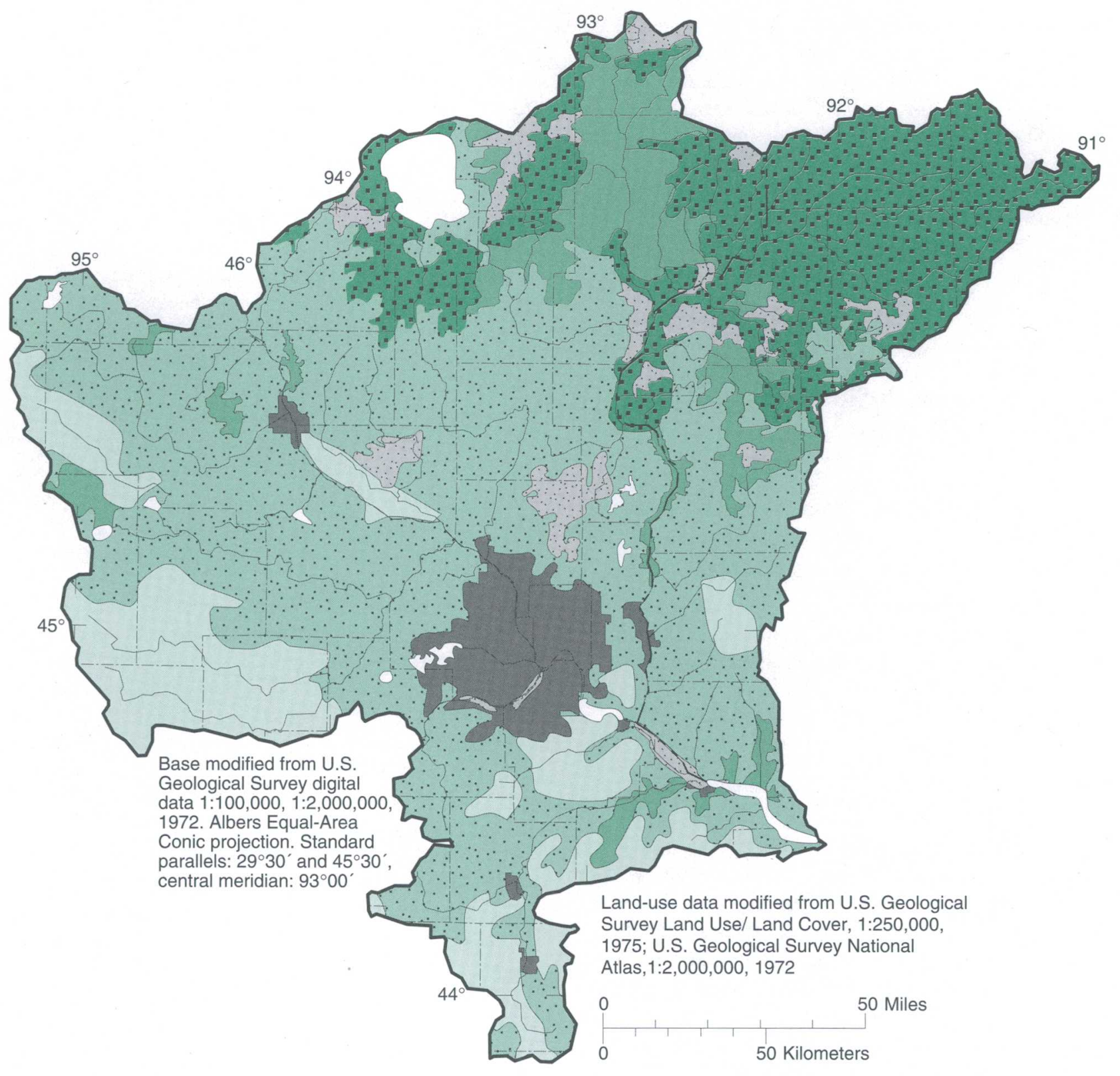

EXPLANATION

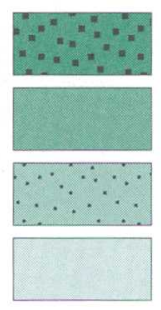

Forest and woodland

Woodland and cropland

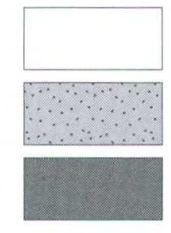

Water

Wetland

Cropland and woodland

Urban

Cropland

Figure 2.--Land cover in the study area. 


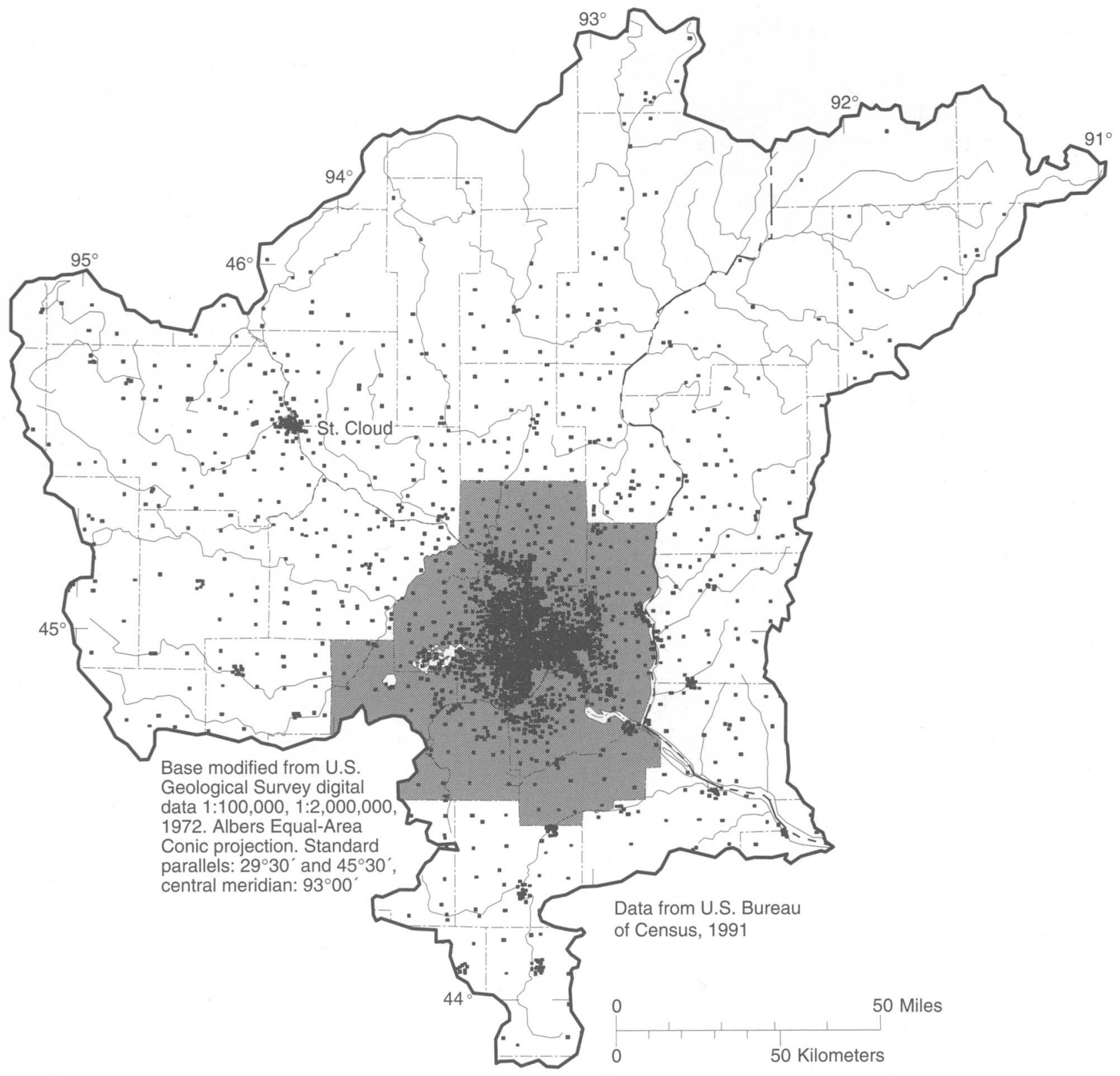

EXPLANATION

Twin Cities metropolitan area

Centroid of census tract representing 1,000 people

Figure 3.-- Population distribution in the study area. 
progressively thin toward the northeast and southeast in the study area (Woodward, 1986, Trotta and Cotter, 1973). Along the courses of streams and rivers, unconsolidated sediments were reworked, forming terrace and alluvial deposits of Holocene age. Soils formed on glacial deposits and alluvium in the study area range from heavy, poorly drained clayey soils developed on glacial tills to light, well-drained sandy soils developed on sandy glacial outwash and alluvium. The relatively high permeabilities and low organic-carbon contents of soils formed on sandy outwash are conducive to leaching of VOC's from the land surface to ground water, whereas clayey, organic-rich soils formed on tills are more likely to produce runoff to surface water of VOC's spilled on the land surface. The uppermost aquifers underlying much of the study area are composed of unconfined sand and gravel deposited as glacial outwash and alluvium. The most extensive outwash-covered plains in the study area are located in east-central Minnesota (the Anoka Sand Plain) and in northwestern Wisconsin (fig. 4). Water in sand and gravel aquifers in the study area is generally of acceptable quality for domestic, industrial, and irrigation purposes. However, unconfined sand and gravel aquifers with water tables located only a few feet below the land surface are susceptible to contamination by substances such as VOC's leaching from spills or leaks on or near the land surface (Ruhl, 1987). Seepage from sand and gravel aquifers can also affect the quality of surface water and the quality of water in hydraulically connected bedrock aquifers in the study area.

The principal bedrock aquifers in the eastern part study area are composed of sandstones and dolomites of Precambrian to Ordovician age in the Hollandale Embayment (Delin and Woodward, 1982;) (fig. 5). Bedrock aquifers are the most commonly used sources of ground water in the study area due to the larger yields generally obtainable from wells completed in these aquifers. Up to 1,200 feet of sedimentary strata of Paleozoic age underlie the TCMA, the location of most of the ground-water withdrawals in the study area. The bedrock hydrogeologic system of the eastern part of study area can be divided into four major aquifers, which are separated by confining units. The aquifers are, in descending order: the St. Peter, Prairie du ChienJordan (Prairie du Chien-Trempeleau in Wisconsin), Franconia-Ironton-Galesville (Tunnel City-Wonewoc in Wisconsin), and the Mt. Simon-Hinckley-Fond du Lac (Adolphson and others, 1981). Confining units for these aquifers are, in descending order: the PlattevilleGlenwood, the basal part of St. Peter, St. LawrenceFranconia (the Franconia Formation is a fine-grained silty sandstone that also is utilized locally as an aquifer), and the Eau Claire. In the western part of the study area, glacial deposits are underlain by aquifers composed of sandstones of Cretaceous age and of fractured igneous and metamorphic rocks of Precambrian age (Woodward and Anderson, 1986; Anderson, 1986). Fractured igneous rocks of Precambrian age are also sources of water where sand and gravel deposits are thin or where surficial deposits are of low permeability in the northeastern portion of the study area. The bedrock aquifers receive the greatest amount of recharge and are more susceptible to contamination by compounds such as VOC's where these units are unconfined and subcrop beneath thin, permeable unconsolidated deposits.

\section{Sources and Uses of Volatile Organic Compounds and their Potential Effects on Water Quality}

VOC's include hundreds of natural and synthetic compounds with thousands of uses. VOC's are defined as carbon-containing compounds with vapor pressures greater than 13 to 130 pascals at standard temperature $\left(25^{\circ} \mathrm{C}\right)$ and pressure $(101,325$ pascals) (Kotzias and Sparta, 1993). VOC's are present in nature in plants and soils and in synthetic items such as solvents, paints, and petroleum. The multitude of natural and synthetic sources and the widespread use of VOC's make them ubiquitous in the environment. VOC's have been detected in the atmosphere, and in surface- and groundwater samples worldwide (Ciccioli, 1993, Kotzias and Sparta, 1993). VOC's are integral components of industrialized societies, and commonly are used in manufacturing, industry, and agriculture. VOC's are used to manufacture paints, adhesives, wood preservatives, pesticides, solvents, petroleum products, fire extinguishers, organic chemicals, deodorants, cosmetics, pharmaceuticals, rubber products, explosives, photographic materials, and refrigerants (Verschueren, 1983). VOC's also are used as solvents, metal polishers, degreasing agents, odor controllers, mineral and salt separators, hydraulic fluids, dry cleaning agents, thermoelectric fluids, leak detectors, penetrating agents, scouring compounds, and extracting agents for heatsensitive compounds (Verschueren, 1983). VOC's also are applied directly to soils as active and inactive components of fertilizers, herbicides, insecticides, insect repellants, fungicides, fumigants, nematocides, rodenticides, soil conditioners and sterilants (Verschueren, 1983). Lesser uses of VOC's include uses as food additives and antioxidants, tobacco flavoring, and fermentation regulators (Verschueren, 1983). 


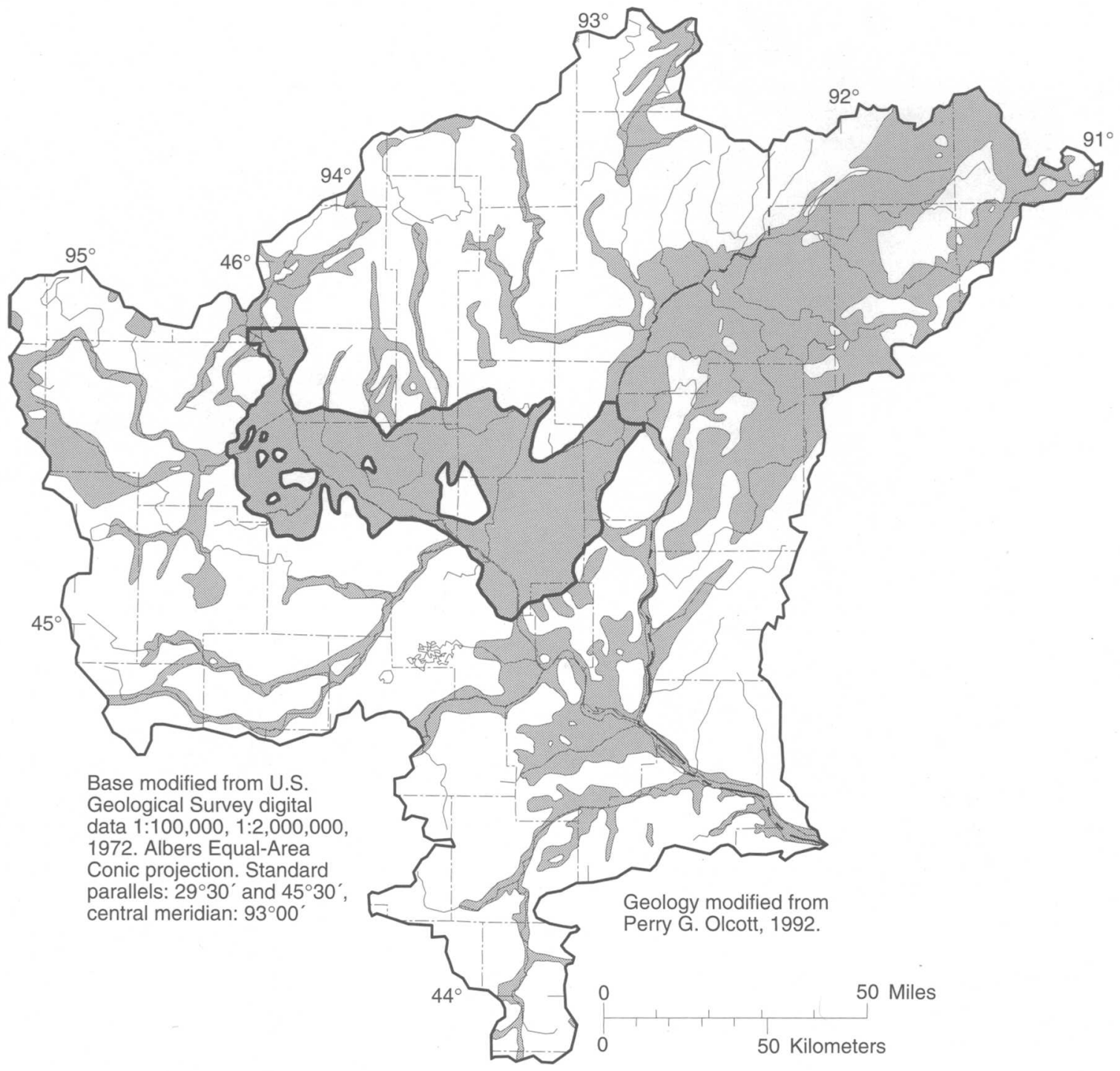

EXPLANATION

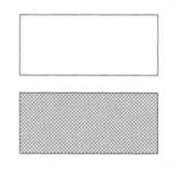

Glacial till, unsorted and unstratified deposits

Glacial outwash, coarse-grained glacial-lake sediment, and coarse- and fine-grained alluvium

Anoka Sand Plain boundary

Figure 4.--Surficial geology in the study area.

The partitioning of VOC's between air, water, and soil is controlled by the physical properties of the compounds and the surrounding environment. Physical properties of VOC's vary by compound, but the property that most controls the fractionation of a VOC between air and water is the Henry's law constant--the equilibrated proportion of the concentration of a compound dissolved in water to the partial pressure of a compound in the atmosphere above the water (Kotzias and Sparta, 1993). Compounds with low Henry's law constants are more likely to be in the aqueous phase, whereas compounds with high constants are more likely to be in the gas phase. Because VOC's have relatively high Henry's law constants, they readily volatilize to the atmosphere (Kotzias and Sparta, 1993). In surface water, the evaporative half lives of many VOC's, such as 


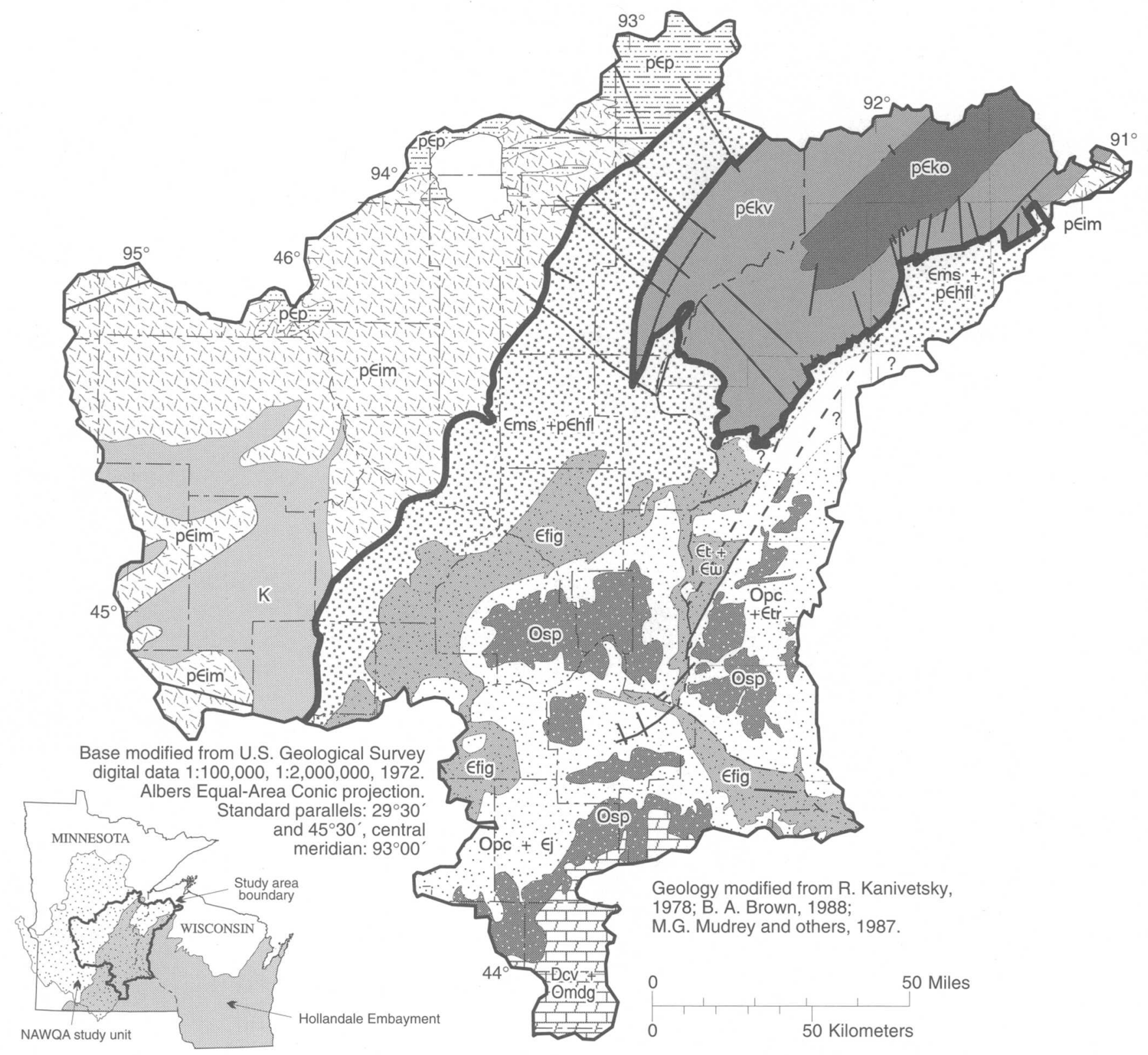

Figure 5.--Bedrock hydrogeology in the study area.

chloroform or methylene chloride, are less than an hour (Verschueren, 1983). Although VOC's are ubiquitous in the environment, rapid volatilization from open water generally keeps concentrations in surface water near or below detection limits (Kotzias and Sparta, 1993). In soils and ground water, however, VOC's may exist much longer due to higher confining pressures and lack of contact with the atmosphere.

The distribution of VOC's in soils is complicated by the physical properties of both VOC's and soils. VOC's may partition into three phases in soils: liquid, solid, or vapor. Determination of the distribution of a VOC in soil must include analysis of the physical properties of the VOC and how these properties relate to each soil phase. Henry's law constants govern the distribution of VOC's between air and water in soil, whereas the polarity of a VOC determines whether the VOC will partition to soil water or soil particles. Polar VOC's, such as carboxylic acids, partition to the soil-water phase while nonpolar compounds, such as aromatic hydrocarbons, partition to organic materials in 


\section{EXPLANATION}

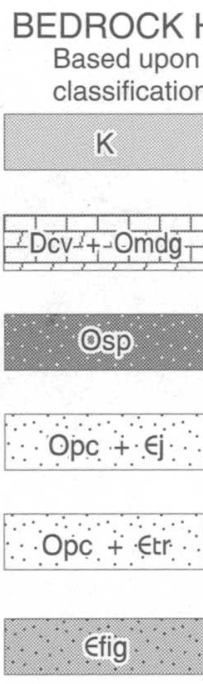

$\dot{t}+\dot{E}$

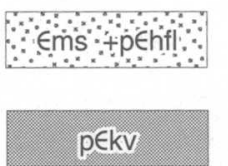

peko
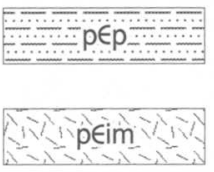

$?$

\section{PRAIRIE DU CHIEN-JORDAN \\ high yields, good water quality. \\ PRAIRIE DU CHIEN-TREMPEALEAU \\ --in Wisconsin \\ Dolomite, sandstone. Moderate to high yields, good water quality. \\ FRANCONIA-IRONTON-GALESVILLE \\ Sandstone, some shale. Moderate to high yields, good water quality. \\ TUNNEL CITY-WONEWOC-EAU CLAIRE \\ --in Wisconsin \\ Sandstone, some shale. Moderate to high yields, good water quality. \\ MT. SIMON-HINCKLEY-FOND DU LAC Sandstone; siltstone, shale at base. Moderate to high yields, good water quality in north, slightly saline in south. \\ KEWEENAWAN SEDIMENTARY AND \\ VOLCANIC ROCKS \\ . Low, uncertain yields, variable water quality. \\ ORONTO GROUP SANDSTONES \\ Feldspathic sandstone, siltstone, shale \& conglomerate. Low to moderate yeilds. \\ PRECAMBRIAN METASEDIMENTARY \\ ROCKS \\ Argillite, slate, metagraywacke. Low yields, \\ mostly good water quality. \\ PRECAMBRIAN IGNEOUS AND \\ METAMORPHIC ROCKS \\ Minor aquifers, in fractured zones.}

UNKNOWN

Faults, dashed where approximated

Hollandale Embayment boundary soils (Kliest, 1993). Thus, soils rich in organic carbon have relatively high rates of adsorption of nonpolar VOC's, whereas polar VOC's tend to partition to the aqueous phase. VOC's partitioned into soil water are susceptible to transport to shallow ground water. The presence of VOC's in ground water is of concern because high atmospheric pressures and a general lack of degrading agents (microbial activity, sunlight, oxidation) allow VOC's to exist for months or years in ground water.
Exposure to VOC's is an important human-health concern. Some VOC's are suspected carcinogens (benzene, trichloroethene, tetrachloroethene, 1,1dichloroethene, and chloroform) and others may be toxic to infants and children (hexachlorobenzene) (U.S. Environmental Protection Agency, 1994a; Agency for Toxic Substances and Disease Registry, 1990). Because of these concerns, the U.S. Environmental Protection Agency (USEPA) was mandated by the Safe Drinking Water Act to establish drinking-water standards limiting the allowable concentrations of many VOC's in drinking water including Maximum Contaminant Levels and Maximum Contaminant Level Goals (MCL's and MCLG's, respectively (table 1)). MCL's are enforceable standards, based on toxicity studies and treatment feasibility. MCLG's are nonenforceable concentration goals which are equal to zero for carcinogens or to the lifetime safe exposure concentration for noncarcinogens (U.S. Environmental Protection Agency, 1995).

Because of the known or suspected adverse effects of some VOC's on humans and aquatic organisms, ambient freshwater criteria for many VOC's have been established by the USEPA, as mandated by Section 304(a) of the Clean Water Act, to provide nonenforceable guidelines for development of standards by states (table 1). Criteria established to protect human health are based on calculated adverse health risks of ingesting water or organisms (such as fish and shellfish) from freshwater. Ambient freshwater criteria designed to protect aquatic organisms are based on toxicity calculations for both acute (from instantaneous to one-hour) and chronic (from one- to four-day) exposure to toxic compounds (Ware, 1994).

Many VOC's are also regulated as hazardous wastes by the USEPA under the authority of the Resource Conservation and Recovery Act (RCRA) and the Comprehensive Environmental Response, Compensation and Liabilities Act (CERCLA) (table 1). These acts were designed to minimize release of hazardous substances such as VOC's to the environment.

VOC's may be emitted at thousands of locations in the study area. There are 32 facilities registered with the USEPA to discharge VOC's to surface water (fig. 6), 26 sites listed on the National Priorities List (NPL) of the USEPA's CERCLA Program (all located in the TCMA), 2 Installation Rehabilitation Program (IRP) sites (the equivalent of NPL sites on military installations), and 260 potential NPL sites (most of which are in the TCMA). In 


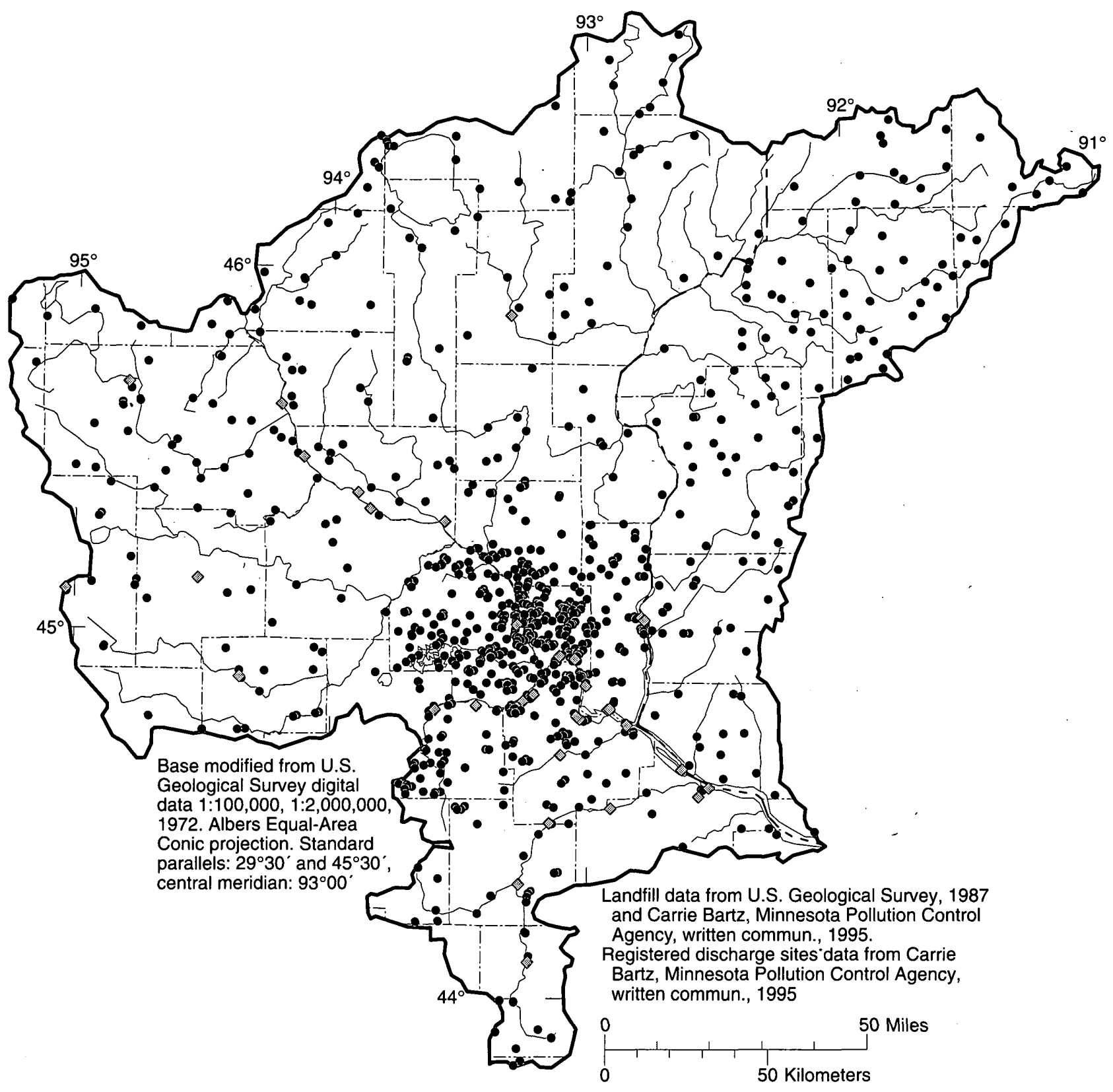

EXPLANATION

- Landfill or historical open dump

- Major registered discharge site

Figure 6.--Locations of landfills and historical open dumps and locations of major registered sites discharging volatile organic compounds to streams in the study area. 
addition to those sites, there are several hundred landfills (abandoned or in operation and historical dumps (fig. 6)), hundreds of factories, and approximately 900 print shops and publishers, 1,300 leaking underground petroleum storage tanks, and 5,000 gasoline retailers and automobile service facilities in the study area, all of which are potential sources of VOC's to the atmosphere, surface water, or ground water (Leete, 1991, U.S. Environmental Protection Agency, 1994b; Right to Know Network, electronic commun., 1995; Minnesota Pollution Control Agency, 1990).

The Toxic Release Inventory (TRI), a data base of toxic compounds released to air, land, and water maintained by the USEPA, provides an indication of amounts of VOC's discharged in the study area by commercial and industrial facilities registered with that agency. The amounts of VOC's actually released to the atmosphere and to surface water in the study area may be considerably higher, as the TRI generally only records monitored discharges from larger industrial facilities, and greater amounts of VOC's may be discharged to the environment at thousands of smaller sites and through unregistered disposal of these compounds. All of the target VOC's, except 1,1dichloroethane and 1,2-dichloroethane, are listed among the most commonly discharged VOC's in the study area. Total discharges to air, land, and surface water of those compounds in the study area (in pounds in 1992) were as follows: toluene--5,708,492; xylene (all isomers)-3,353,148; 1,1,1-trichloroethane--1,697,903; trichloroethene--627,018; ethylbenzene--510,715; benzene--230,673; and tetrachloroethene--152,073 (U.S. Environmental Protection Agency, 1994b). Direct discharges of some of those compounds to surface water in the study area in 1992, which were substantially less than emissions to the atmosphere, were as follows: toluene--26 lbs, xylene--239 lbs, 1,1,1-trichloroethane-$41 \mathrm{lbs}$, and benzene--16 lbs (U.S. Environmental Protection Agency, 1994b). In addition to those target VOC's, a total of 53,000 pounds of one trihalomethane compound, chloroform, was released to the atmosphere by factory stacks in the study area (U.S. Environmental Protection Agency, 1994b). Locations and quantities of releases of VOC's to air, land, and surface water in the study area are shown in figures $7 \mathrm{a}$ and $7 \mathrm{~b}$.

\section{Sources of data}

Sources of VOC data in surface and ground water used for this report include the Water Storage and Retrieval (WATSTORE) data base of the USGS; the Safe Drinking Water Program of the MDH; the GroundWater Monitoring and Assessment and Ambient Ground-Water Monitoring Programs of the MPCA (data from the Ambient Ground-Water-Monitoring Program was retrieved from the STORET data base of the USEPA); the Ground-Water-Quality Monitoring Network of the WDNR; the River-Toxics Monitoring Program of the MCES, and the National Pollutant Discharge Elimination System (NPDES) data from the City of Minneapolis Public Works Department. The purposes of sampling programs conducted by these agencies, the numbers of stations or wells sampled, the frequencies of sampling, and periods of record of these data bases are listed in table 2 .

\section{Methods of data review}

The data summarized in this report were compiled from paper documents and electronic data bases maintained by Federal, State and local agencies listed in table 2. For summarization in this report, all VOC analyses listed as non-detects were converted to values less than the laboratory reporting limits. Surface-waterquality data collected by each agency are presented separately, grouped by sampling station because the included agencies sampled surface water at different stations at different frequencies with differing samplecollection protocols. All surface-water-quality data collected at each site are summarized in this report.

Ground-water quality data were grouped by aquifer type (sand and gravel or bedrock) to examine differences in water quality between those two major types of aquifers. Aquifer-type designations for wells sampled by the USGS and MDH were made by matching unique numbers of the wells (6-digit well identification numbers assigned by the Minnesota Geological Survey (MGS)) to aquifer codes for those wells in the Ground-Water Site Inventory (GWSI) of the USGS and the County Well Index (CWI) of the MGS for wells in Minnesota. Aquifer designations for wells sampled in Wisconsin by WDNR were made by examining well logs at regional WDNR offices. Because wells were sampled variable numbers of times, only the water-quality data from the last sample collected from each well were included in data sets. This selection procedure avoids overweighting data from the more frequently analyzed wells and is more representative of recent ground-water quality. The most recent ground-water-quality data collected in widespread networks in the study area by the agencies listed in table 2 were grouped together (with the exception of THM's) because these agencies use similar collection and USEPA-approved analytical methods (Wershaw and others, 1987; Friedman and Erdmann, 1982; Wood, 1976; Minnesota Department of Health, 1993; Schlothauer, 1994), or more sensitive analytical methods (Rose and Schroeder, 1995), have similar quality-assurance and quality-control practices, and the 

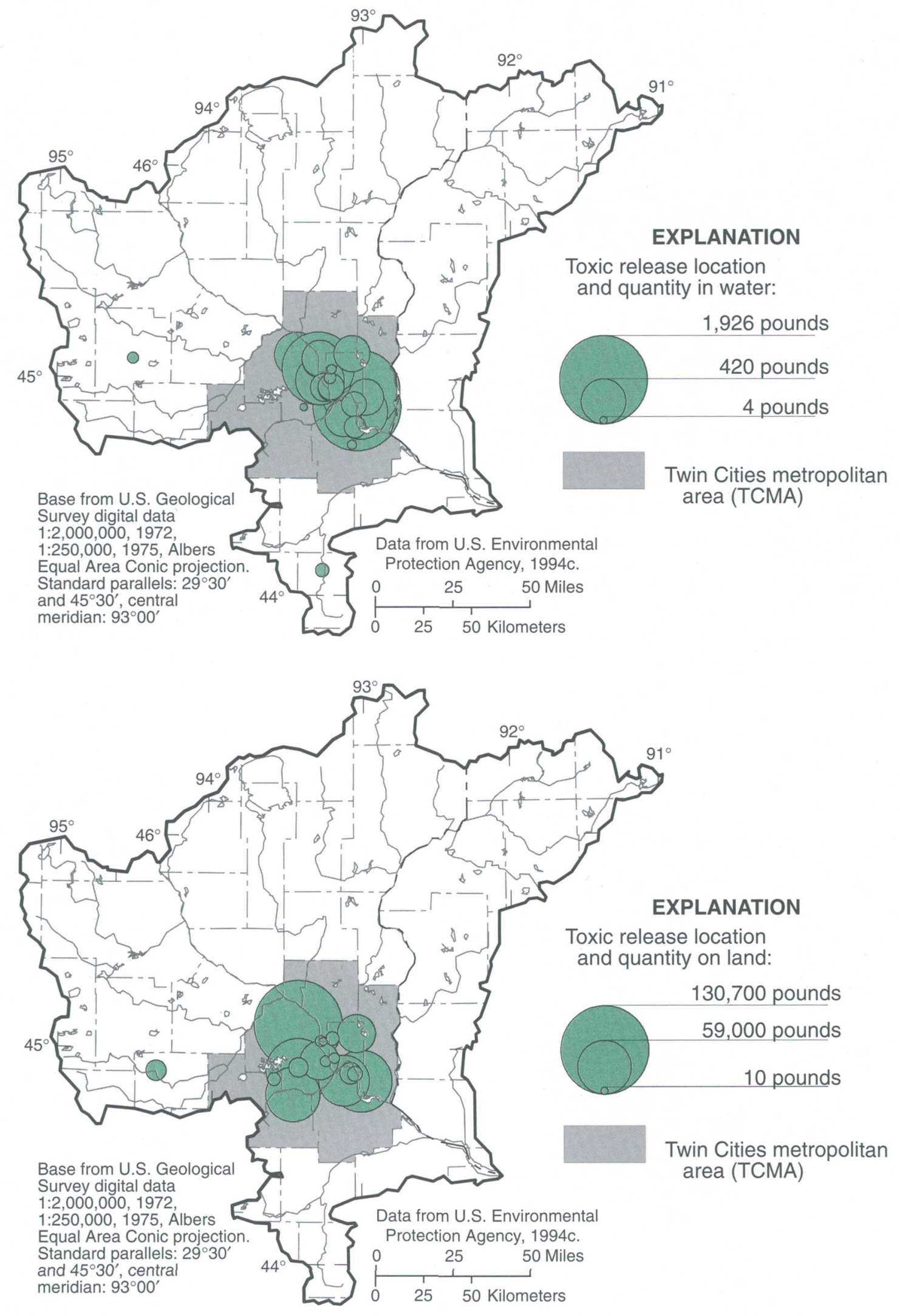

Figure 7a.--Locations and quantities of releases of volatile organic compounds to water and land in the study area, 1992. 


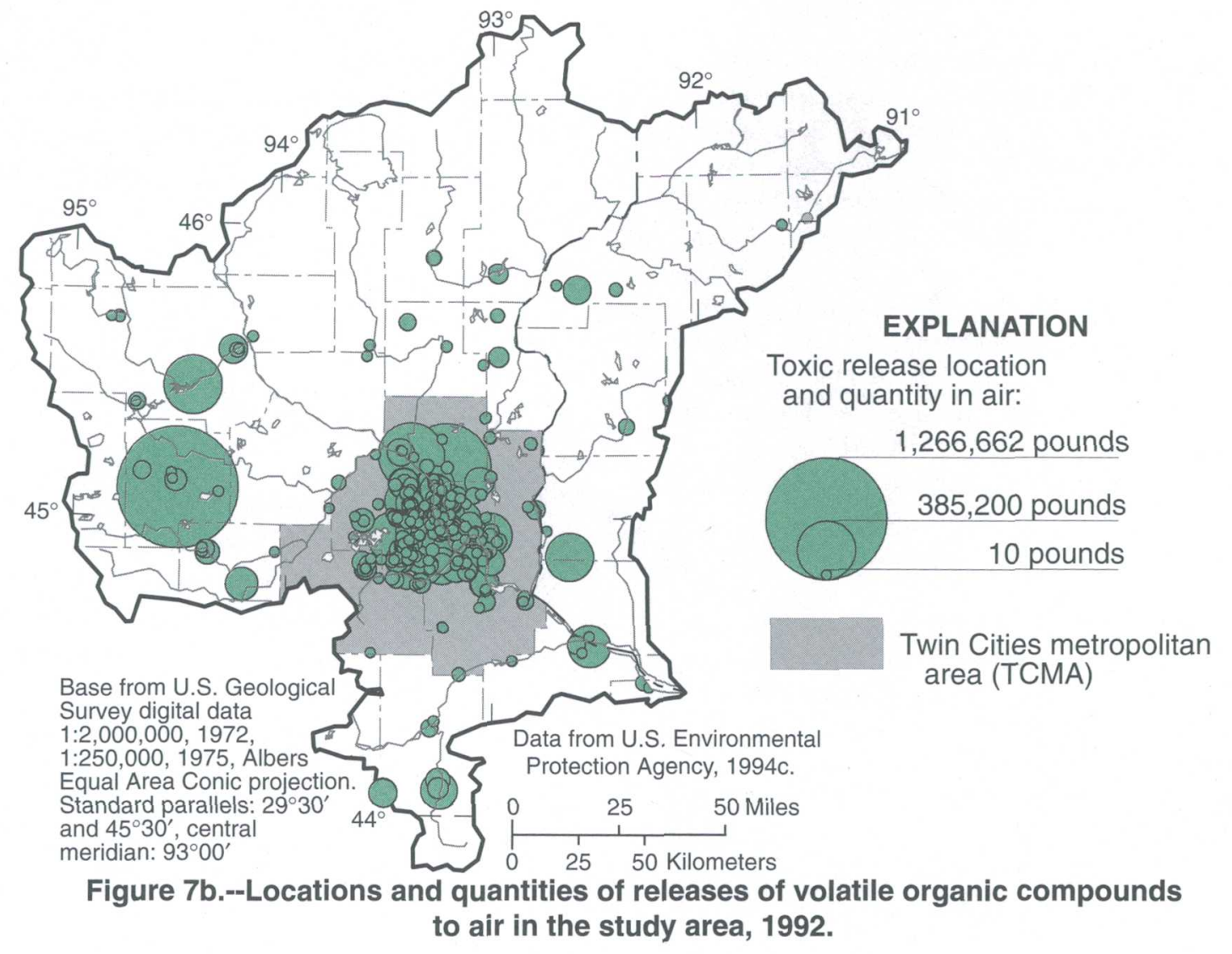

Table 2.--Sources of regional volatile organic compound data in the study area

\begin{tabular}{|c|c|c|c|c|}
\hline Source & General purpose for collecting data & $\begin{array}{l}\text { Number of wells } \\
\text { and/or stations in } \\
\text { the study area }\end{array}$ & $\begin{array}{l}\text { Sampling } \\
\text { frequency }\end{array}$ & Period of record \\
\hline $\begin{array}{l}\text { U.S. Geological Survey } \\
\text { Water Storage and Retrieval } \\
\text { (WATSTORE) data base }\end{array}$ & $\begin{array}{l}\text { Volatile organic compound analyses made } \\
\text { as part of regional surface- and ground- } \\
\text { water-quality investigations conducted in } \\
\text { cooperation with state and local agencies. }\end{array}$ & 48 & Variable & $1987-94$ \\
\hline $\begin{array}{l}\text { Minnesota Department of } \\
\text { Health Safe Drinking Water } \\
\text { Program }\end{array}$ & $\begin{array}{l}\text { Determine compliance of treated surface- } \\
\text { and ground-water community water sup- } \\
\text { plies with State and Federal drinking water } \\
\text { standards. }\end{array}$ & 143 & $\begin{array}{l}\text { From quarterly to } \\
\text { every } 3 \text { years }\end{array}$ & 1988-94 \\
\hline $\begin{array}{l}\text { Minnesota Pollution Control } \\
\text { Agency Ground Water } \\
\text { Monitoring and Assessment } \\
\text { Program }\end{array}$ & $\begin{array}{l}\text { Establish baseline ground-water quality } \\
\text { conditions. }\end{array}$ & 155 & Every 5 years & 1992-94 \\
\hline $\begin{array}{l}\text { Minnesota Pollution Control } \\
\text { Agency Ambient Ground } \\
\text { Water Monitoring Program }\end{array}$ & $\begin{array}{l}\text { Establish baseline ground-water quality } \\
\text { conditions. }\end{array}$ & 140 & 2 or more times & 1978-91 \\
\hline $\begin{array}{l}\text { Wisconsin Department of Nat- } \\
\text { ural Resources Ground Water } \\
\text { Quality Monitoring Network }\end{array}$ & $\begin{array}{l}\text { Monitor the quality of untreated ground- } \\
\text { water used for public water supplies and } \\
\text { private wells. }\end{array}$ & 184 & $\begin{array}{l}\text { Quarterly to } \\
\text { annually }\end{array}$ & 1983-94 \\
\hline $\begin{array}{l}\text { Metropolitan Council } \\
\text { Environmental Services River } \\
\text { Toxics Monitoring Program }\end{array}$ & $\begin{array}{l}\text { Determine the effectiveness of wastewater } \\
\text { treatment programs and compliance with } \\
\text { Federal and State regulations. }\end{array}$ & 16 & $\begin{array}{l}\text { Annually, in } \\
\text { autumn }\end{array}$ & $1982-92$ \\
\hline $\begin{array}{l}\text { City of Minneapolis Public } \\
\text { Works Department }\end{array}$ & $\begin{array}{l}\text { Storm-water runoff permit application for } \\
\text { the USEPA's National Pollution Discharge } \\
\text { Elimination System }\end{array}$ & 8 & $\begin{array}{l}3 \text { storms } \\
\text { separated by at } \\
\text { least } 21 \text { days }\end{array}$ & 1992 \\
\hline
\end{tabular}


incidences of VOC detection were similar in those data sets. Because chlorination of water can induce the formation of THM's, THM concentrations in samples collected by $\mathrm{MDH}$, which collected mostly chlorinated water samples, are considered separately from THM concentrations in unchlorinated water samples analyzed by the other agencies. Chi-square tests of contingency tables (Helsel and Hirsh, 1992) of detection frequencies for the target VOC's and the THM's (excluding MDH data) in ground water indicated that the ground-waterquality data collected by the agencies listed in table 2 were similar at a confidence level of 95 percent for 24 out of 30 VOC/aquifer-type data groups.

\section{Acknowledgments}

The authors express appreciation to the following persons and agencies for their assistance in compiling the data in this report and for their guidance during the preparation of this report: Doug Mandy of the Minnesota Department of Health; Don Jakes, Tom Clark, and YuanMing Hsu of the Minnesota Pollution Control Agency; Randall Clark, Jack Bates, and Nadene Cable of the Wisconsin Department of Natural Resources; Terrie O'Dea of Metropolitan Council Environmental Services; and Jodi Polzin of the city of Minneapolis Public Works Department.

\section{Volatile Organic Compounds in Water}

Some of the most commonly used VOC's have been detected in both surface and ground water in the study area. VOC's were less commonly detected in surface water than in ground water, because surface water is subject to turbulent aeration and atmospheric outgassing. Although not commonly detected in surface water, VOC's have been detected in downstream of urban areas.

\section{- Surface Water}

As of 1990 , approximately 75 percent of the 2,700 million gallons of water used per day in the study area were from surface-water sources, about 1,730 million gallons per day of which was used for thermoelectric purposes (U.S. Geological Survey, National Water-Use data base, electronic commun., 1995). Surface water withdrawn from the Mississippi River is treated and used as a source of potable water primarily by the cities of Minneapolis, St. Paul, and St. Cloud in the study area. Three agencies have sampled surface water for VOC's upstream and downstream of urban areas: the $\mathrm{MDH}$, the MCES, and the City of Minneapolis (fig. 8).
The largest data set of the three, in terms of the number of sites sampled and period of record, was collected by the MCES. ,The MCES staff collected grab samples from sixteen sites upstream and downstream of MCES wastewater-treatment plants on the Mississippi, Minnesota, St. Croix, and Vermillion Rivers during autumn low-flow periods from October 1982 through September 1992. Five VOC's were detected in water samples collected at 6 of the 16 sites sampled by the MCES (table 3), which were analyzed for a suite of 28 VOC's (acrolein, acrylonitrile, benzene, bromodichloromethane, bromoform, bromomethane, chlorobenzene, chloroethane, chloroform, chloromethane, dibromochloromethane, 1,1dichloroethane, 1,2-dichloroethane, 1,1-dichloroethene, trans-1,2-dichloroethene, 1,2-dichloropropane, cis-1,3dichloropropene, trans-1,3-dichloropropene, 1,1,2,2tetrachloroethane, tetrachloroethene, toluene, 1,1,1trichloroethane, 1,1,2-trichloroethane, trichloroethene, trichlorofluoromethane, meta-xylene, para-xylene, and ortho-xylene). A 29th VOC, methylene chloride, was analyzed for but is not summarized in this report because of suspected contamination of samples by that compound (Metropolitan Waste Control Commission, 1994).

Samples of finished water from public water supplies with surface-water sources were analyzed for a suite of 64 VOC's by the MDH. From 1988 through 1993, 14 to 16 samples were collected from each of those water supplies before distribution in Minneapolis, St. Paul, and St. Cloud (table 4). Two of the target VOC's--benzene and trichloroethene, were detected in samples from those water supplies. The greatest number of detections of target VOC's was in samples from the water supply for St. Paul. St. Paul obtains surface water from the Vadnais chain of lakes, augmented by water from the Mississippi River which is pumped into the lakes for storage. Fewer VOC's were detected in the water supplies for St. Cloud and Minneapolis, which obtain surface water directly from the Mississippi River.

The City of Minneapolis contracted with HDR Engineering, Inc., to sample storm-water runoff as part of the permit application for the USEPA's National Pollutant Discharge Elimination System (NPDES) (U.S. Office of Technology Assessment, 1987). From April through August of 1992, stormwater runoff samples were collected during three or four storm events at each of eight small urban watersheds in Minneapolis and 


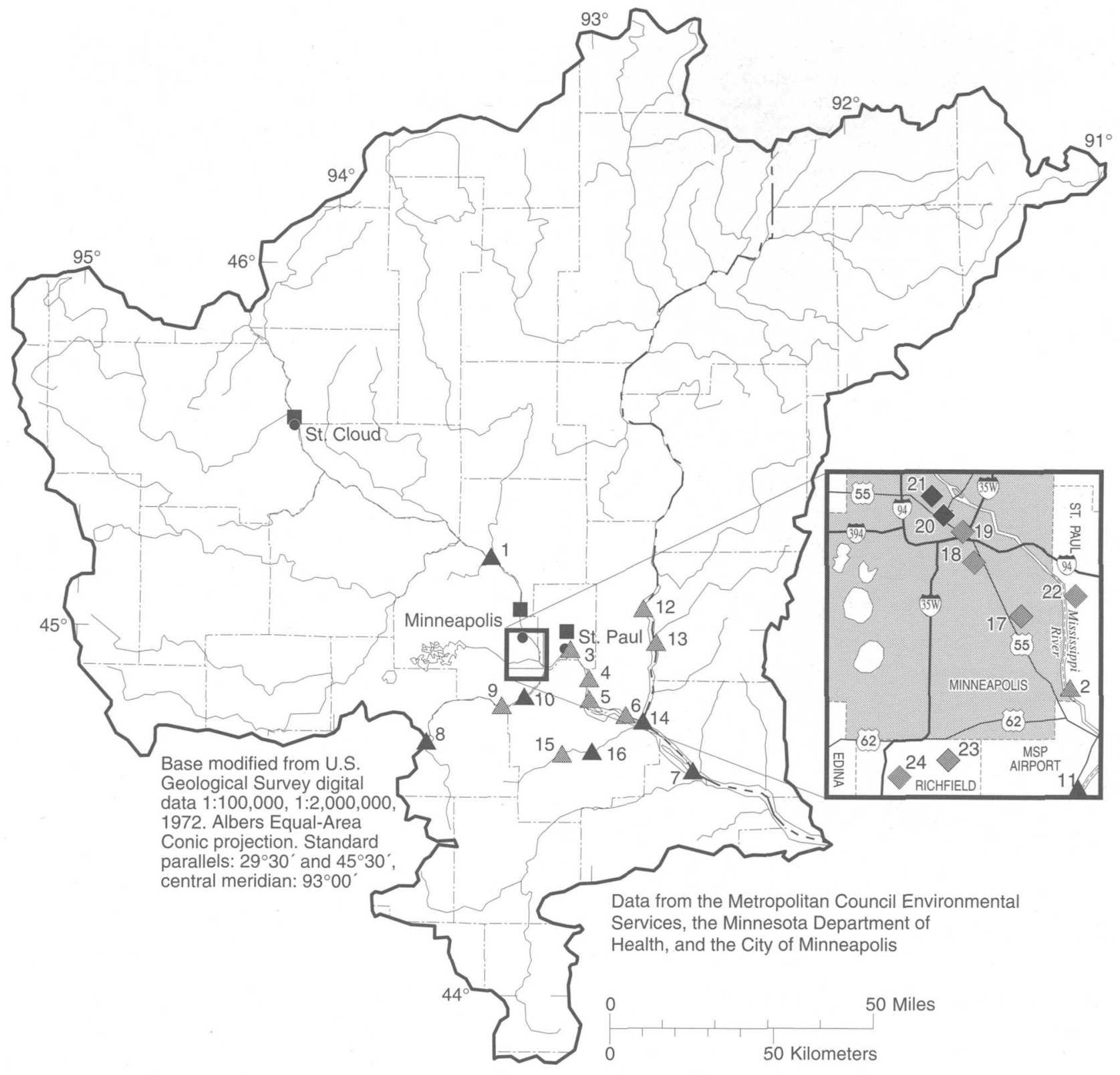

EXPLANATION

$\triangle^{5}$ River location site sampled by MCES. Solid black symbol indicates VOC's detected. Number identifies site and corresponds to site number in table 3.

- Municipal water supply site sampled by MDH with VOC's detected

24 Stormwater runoff site sampled by the City of Minneapolis. Solid black symbol indicates VOC's detected. Number identifies site and corresponds to site number in table 5.

Figure 8.--Surface-water sites sampled by Metropolitan Council Environmental Services (MCES), the Minnesota Department of Health (MDH), and the City of Minneapolis for volatile organic compounds (VOC's) in the study area, October 1982-August 1992. 
Table 3.--Summary of volatile organic compound concentrations in samples collected from 16 surface-water stations sampled by the Metropolitan Council Environmental Services in the study area, Minnesota.

[Concentrations are reported in micrograms per liter, --, no detections]

\begin{tabular}{|c|c|c|c|c|c|c|c|}
\hline & Station number and name & Year & $\begin{array}{l}\text { Number of } \\
\text { samples }\end{array}$ & Compounds detected & $\begin{array}{l}\text { Number of } \\
\text { detections }\end{array}$ & $\begin{array}{l}\text { Detected } \\
\text { concentrations }\end{array}$ & $\begin{array}{l}\text { Range of detection } \\
\text { limits }\end{array}$ \\
\hline 1) & $\begin{array}{l}\text { Mississippi River at Anoka, } \\
\text { Minnesota }\end{array}$ & $\begin{array}{l}1982-84 \\
1986-92\end{array}$ & 10 & Benzene & 1 & 27.3 & $1_{3.0-15.0}$ \\
\hline 2) & $\begin{array}{l}\text { Mississippi River at Lock and } \\
\text { Dam \#1 }\end{array}$ & $\begin{array}{l}1982-84 \\
1986-92\end{array}$ & 10 & None & 0 & -- & ${ }^{2} 0.8-100$ \\
\hline 3) & $\begin{array}{l}\text { Mississippi River at St. Paul, } \\
\text { Minnesota }\end{array}$ & $\begin{array}{l}1982-84 \\
1986-92\end{array}$ & 10 & None & 0 & -- & ${ }^{2} 0.8-100$ \\
\hline 4) & $\begin{array}{l}\text { Mississippi River at Newport, } \\
\text { Minnesota }\end{array}$ & $\begin{array}{l}1982-84 \\
1986-92\end{array}$ & 10 & None & 0 & -- & ${ }^{2} 0.8-100$ \\
\hline 5) & $\begin{array}{l}\text { Mississippi River at Grey } \\
\text { Cloud Island }\end{array}$ & $\begin{array}{l}1982-84 \\
1986-92\end{array}$ & 10 & None & 0 & -- & ${ }^{2} 0.8-100$ \\
\hline 6) & $\begin{array}{l}\text { Mississippi River at Lock and } \\
\text { Dam \#2 }\end{array}$ & $\begin{array}{l}1982-84 \\
1986-92\end{array}$ & 10 & None & 0 & -- & ${ }^{2} 0.8-100$ \\
\hline 7) & $\begin{array}{l}\text { Mississippi River at Lock and } \\
\text { Dam \#3 }\end{array}$ & $\begin{array}{l}1982-84 \\
1986-92\end{array}$ & 10 & Acrylonitrile & 1 & 0.6 & $1_{1.2-100}$ \\
\hline 8) & $\begin{array}{l}\text { Minnesota River at Jordan, } \\
\text { Minnesota }\end{array}$ & $\begin{array}{l}1982-84 \\
1986-92\end{array}$ & 10 & None & 0 & -- & ${ }^{2} 0.8-100$ \\
\hline 9) & $\begin{array}{l}\text { Minnesota River at Savage, } \\
\text { Minnesota }\end{array}$ & 1986 & 1 & None & 0 & -- & ${ }^{2} 0.8-100$ \\
\hline 10) & $\begin{array}{l}\text { Minnesota River near NSP } \\
\text { Black Dog Power Plant }\end{array}$ & $1987-92$ & 5 & Trichloroethene & 1 & 2.4 & $1_{2.3-13.0}$ \\
\hline 11) & $\begin{array}{l}\text { Minnesota River at Fort } \\
\text { Snelling State Park }\end{array}$ & $\begin{array}{l}1982-84 \\
1986-92\end{array}$ & 10 & Acrylonitrile & 1 & 1.6 & ${ }^{2} 0.8-100$ \\
\hline 12) & $\begin{array}{l}\text { St. Croix River at Stillwater, } \\
\text { Minnesota }\end{array}$ & $\begin{array}{l}1984 \\
1986-92\end{array}$ & 8 & None & 0 & -- & ${ }^{2} 0.8-60$ \\
\hline 13) & $\begin{array}{l}\text { St. Croix River at Hudson, } \\
\text { Wisconsin }\end{array}$ & $1982-83$ & 2 & None & 0 & -- & $21.2-100$ \\
\hline 14) & $\begin{array}{l}\text { St. Croix River at Prescott, } \\
\text { Wisconsin }\end{array}$ & $\begin{array}{l}1982-84 \\
1986-92\end{array}$ & 10 & Benzene & 1 & 15.2 & $1_{3.0-15.0}$ \\
\hline 15) & $\begin{array}{l}\text { Vermillion River at } \\
\text { Farmington, Minnesota }\end{array}$ & $1986-92$ & 7 & None & 0 & -- & ${ }^{2} 0.8-60$ \\
\hline 16) & $\begin{array}{l}\text { Vermillion River below } \\
\text { Empire WWTP }\end{array}$ & $\begin{array}{c}1982-84 \\
1986-89 \\
1991-92\end{array}$ & 9 & Chloroethane & 1 & 5.6 & ${ }^{1} 1.8-14.0$ \\
\hline
\end{tabular}

${ }^{1}$ Range of detection limits is given for the detected volatile organic compound.

${ }^{2}$ Range of detection limits is given for the entire suite of volatile organic compounds. 
surrounding communities (fig. 8) and analyzed for a suite of 30 VOC's, with reporting levels ranging from 17.5 micrograms per liter (HDR Engineering, Inc., 1992). Criteria for NPDES sample collection were followed with two exceptions: (1) some sampling events were separated by 21 days rather than 30 ; and (2) some samples were collected using an autosampler rather than manually (HDR Engineering, Inc., 1992). Land uses in the sampled watersheds varied from residential with 20 percent impervious area, to commercial with 44 percent impervious area, to industrial and commercial with 45 percent impervious area. Two VOC's, trichlorofluoromethane and 1,2-dichlorobenzene, were detected in runoff from a watershed with 100 percent commercial use (Target Center, table 5).

Trichlorofluoromethane was also detected in runoff from the watershed with predominantly industrial (48 percent) and commercial (33 percent) uses (Hennepin County Resource Recovery Plant, table 5). The City of St. Paul did not analyze for VOC's for the NPDES permit process (Ann Weber, St. Paul Public Works Department, oral commun., 1995).

\section{Ground Water}

As of 1990 , ground water accounted for 24.9 percent of the 2,700 million gallons of reported daily water withdrawals in the study area (U.S. Geological Survey, National Water-Use data base, electronic commun., 1995). Excluding withdrawals for thermoelectric purposes, ground-water withdrawals accounted for 70 percent of the remaining 970 million gallons of water withdrawn daily in the study area. Approximately onethird of the ground water withdrawn in the study area in 1990 (324 million gallons per day) was from the Prairie du Chien-Jordan aquifer by suburban communities in the TCMA (Andrews and others, in press). Beyond the extent of the Prairie du Chien-Jordan aquifer, sand and gravel aquifers of Pleistocene age and bedrock aquifers composed of sandstones, fractured igneous and

Table 4.--Target volatile organic compounds detected by the Minnesota Department of Health in finished water supplies derived from surface water in the study area, Minnesota

\begin{tabular}{lccc}
\hline \multirow{2}{*}{$\begin{array}{c}\text { Compound (detection } \\
\text { limit in micrograms per }\end{array}$} & \multicolumn{3}{c}{ Number of detections } \\
\cline { 2 - 4 } & Minneapolis & St. Paul & St. Cloud \\
\hline 1,2-dichloroethane (0.2) & 0 & 0 & 2 \\
1,1,1-trichloroethane (0.2) & 0 & 1 & 0 \\
trichloroethene (0.1) & 1 & 0 & 4 \\
benzene (0.2) & 0 & 1 & 0 \\
ethylbenzene (0.2) & 1 & 3 & 0 \\
toluene (0.2) & 0 & 2 & 0 \\
meta+para-xylene (0.2) & 0 & 2 & 0 \\
ortho-xylene (0.2) & 1 & 0 & 0 \\
\hline Number of detections & 3 & 9 & 6 \\
Number of compounds & 3 & 5 & 2 \\
detected & & & 16 \\
Total samples analyzed & 14 & 16 & 16 \\
\hline
\end{tabular}

Table 5.--Summary of volatile organic compound concentrations in samples collected from eight stormwater-runoff stations sampled for Minneapolis, Minnesota.

[Concentrations are reported in micrograms per liter, --, no detections]

\begin{tabular}{lcccc}
\hline \multicolumn{1}{c}{ Station number ${ }^{1}$ and name } & $\begin{array}{c}\text { Number of } \\
\text { samples }\end{array}$ & Compounds detected & $\begin{array}{c}\text { Number of } \\
\text { detections }\end{array}$ & $\begin{array}{c}\text { Detected } \\
\text { concentrations }\end{array}$ \\
\hline 17) Minnehaha Avenue & 3 & -- & -- & -- \\
18) Southside & 3 & -- & -- & -- \\
19) HHH Metrodome & 4 & -- & -- & -- \\
20) Target Center & 3 & trichlorofluoromethane & 1 & 1.6 \\
21) Hennepin County Resource & 4 & trichlorofluoromethane & 1 & 3.6 \\
Recovery Plant & & & & 4.0 \\
22) Seymour Avenue & 4 & -- & -- & -- \\
23) Legion Lake & 4 & -- & -- \\
24) Wood Lake & 4 & -- & -- & - \\
\hline
\end{tabular}

${ }^{1}$ Number shown on figure 8 
metamorphic rocks of Cretaceous, Cambrian, or Precambrian ages are the primary sources of water supply (fig. 5).

The incidence of detectable concentrations of the target VOC's in water samples from widely distributed well networks in the study area is relatively low-approximately 5 percent. Because the target VOC's are not naturally present in ground water (except in the vicinity of petroleum seeps, which do not occur in the study area) and are most commonly detected in the vicinity of spill sites or other identifiable point sources such as leaking underground storage tanks, wells not in close proximity to such sources would not be expected to have detectable concentrations of those VOC's. Conversely, well networks designed to monitor contaminant plumes at VOC disposal or spill sites tend to have markedly higher incidences of VOC detection, reflecting the placement of numerous monitoring wells to sample relatively localized plumes of VOC

contamination in ground water. Data from such networks are not combined in this report with data from widely distributed well networks in this report, because the nature and extent of VOC contamination of ground water at such sites is well documented, and the focus of this report is to evaluate the regional, rather than local, presence of VOC's in ground water.

Ground-water-quality studies conducted by the MDH in the 1980's provide examples of increased frequencies of VOC detection in water from wells sited near VOC emission sites. In 1984 and 1985, the MDH analyzed for VOC concentrations in water samples from 1,801 wells comprising 887 multiple-well, public watersupply systems located in the TCMA or near major industrial centers (Minnesota Department of Health, 1985). Water from 71 (8 percent) of those systems (composed of multiple wells) and from 109 (6.1 percent) of the individual wells had detectable concentrations of VOC's (Minnesota Department of Health, 1985). From 1985-87, the MDH also sampled 300 of the 15,000 non-community public water supply wells (wells at motels, restaurants, and schools) in close proximity to likely VOC emission sites such as dumps, landfills and leaking underground storage tanks throughout the State of Minnesota (Minnesota Department of Health, 1988). VOC's were detected in water from 48 (22.4 percent) of 214 wells outside of the TCMA and in water from 28 (32.6 percent) of 86 wells sampled in the TCMA (Minnesota Department of Health, 1988). A total of 30 VOC's were detected in water from those 300 wells, with the most commonly detected VOC's including 1,1,1-trichloroethane, benzene, ethylbenzene, toluene, and xylenes (Minnesota Department of Health, 1988). Minnesota Department of
Health (1988) also reported that water samples from 26 (about 28 percent) of 93 wells located within 1 mile of dumps and landfills had detectable concentrations of VOC's. From 1986 through 1989, the MDH detected VOC's in 91 ( 8.2 percent) of 1,111 public and private wells located near 132 of the approximately 250 formerly used dumps and currently operated landfills in the TCMA (Minnesota Department of Health, 1989).

\section{Sand and Gravel Aquifers}

Each of the target VOC's were detected in at least one water sample from widely distributed networks of wells completed in sand and gravel aquifers in the study area (figs. 9, 10; table 6). At least one of those compounds was detected in water from 29 of 369 wells completed in sand and gravel aquifers sampled in those networks (fig 9). Many of the water samples from sand and gravel aquifers with detectable concentrations of these VOC's were from wells in the vicinity of registered VOC emission sites, dumps, or landfills (figs. 6, 7a, 7b, and 9). The frequencies of detection of these compounds in water from wells completed in sand and gravel aquifers in the study area ranged from 0.3 percent to 3.6 percent.

Trichloroethene was the most frequently detected target VOC in water sampled from sand and gravel aquifers in the study area (fig. 10, table 6). Trichloroethene is a widely used solvent for dry cleaning, and a degreaser for metals and septic tanks. Water samples from four of the 333 sampled wells (1.2 percent) completed in sand and gravel aquifers had trichloroethene concentrations exceeding the Maximum Contaminant Level (MCL) of 5 micrograms per liter $(\mu \mathrm{g} / \mathrm{L})$ established by the USEPA (U.S. Environmental Protection Agency, 1994a). Like many of the target VOC's, the distribution of trichloroethene concentrations was skewed, with several high outliers (including an analyzed concentration of 7,200 , which is typical of concentrations in a contaminant plume downgradient from a point source). Benzene, a constituent in gasoline, was detected in water samples from 10 of 333 wells ( 3.0 percent) completed in sand and gravel aquifers that were sampled for that compound (fig. 10, table 6). The MCL of $5 \mu \mathrm{g} / \mathrm{L}$ for benzene was only exceeded in one water sample from those wells. Toluene, a common solvent and constituent in paints, was detected in water samples from 4 ( 2.2 percent) of the 181 wells completed in sand and gravel aquifers that were analyzed for that compound. The remaining target VOC's were detected in less than 2 percent of the water samples from wells 


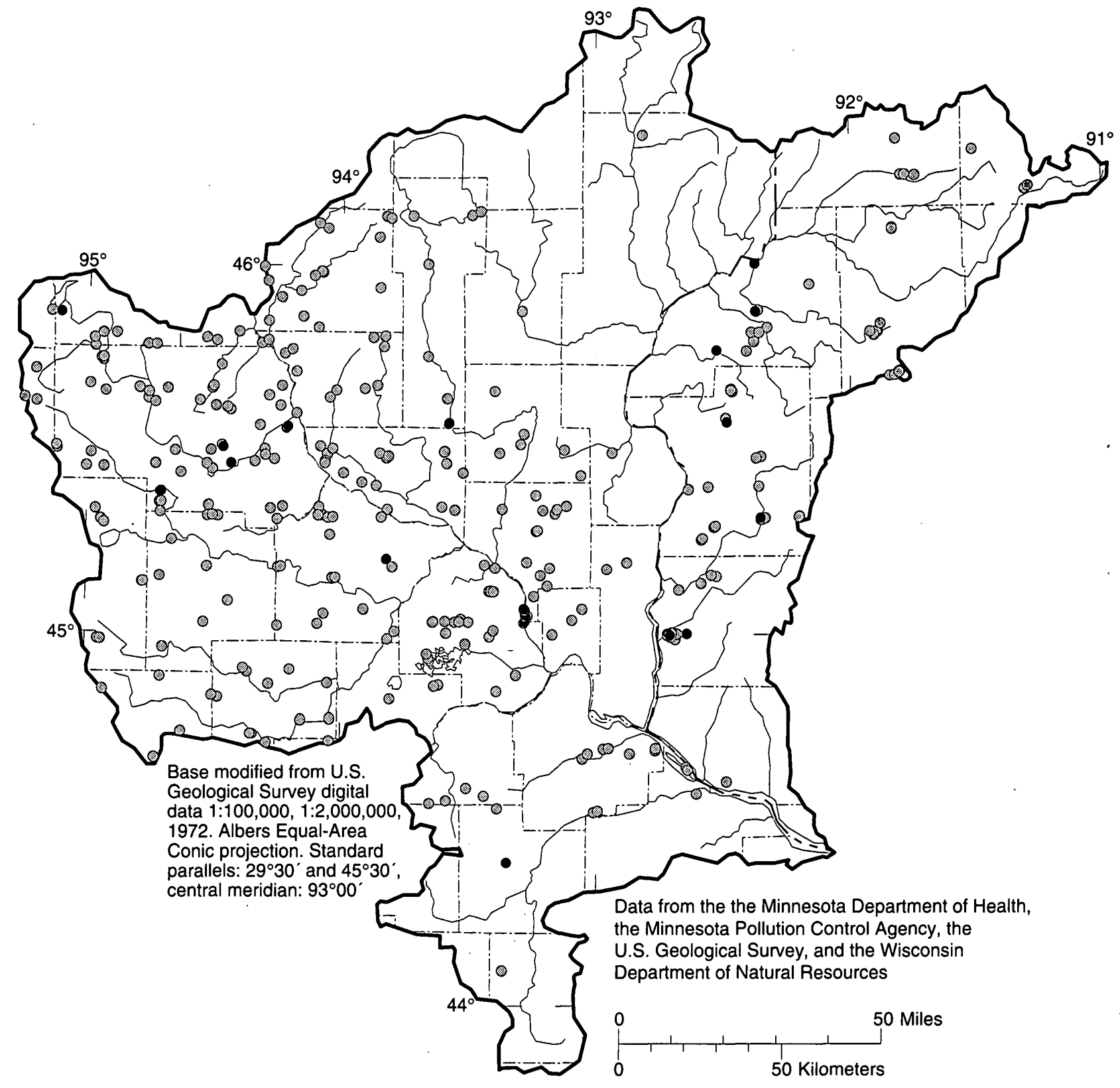

EXPLANATION

- Well sampled for VOC's with none detected

- Well sampled for VOC's with detection of one or more VOC compound

Figure 9.--Locations of sampled wells and locations of wells with detections of target volatile organic compounds (VOC's) for sand and gravel aquifers in the study area. 


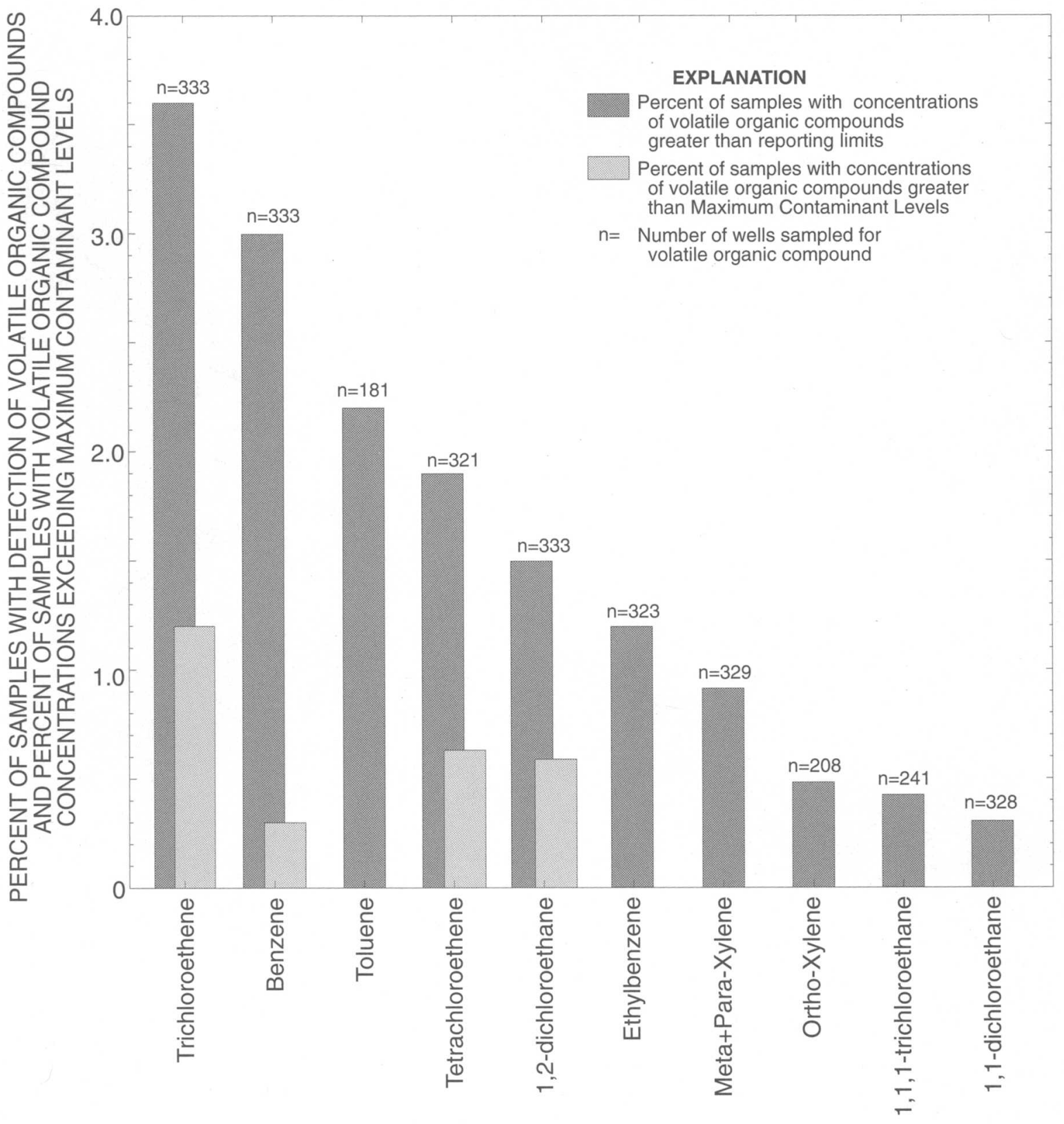

VOLATILE ORGANIC COMPOUND

Figure 10.--Percentages of detection of target volatile organic compounds and percentages of samples with concentrations exceeding of Maximum Contaminant Levels for those compounds in water samples from wells completed in sand and gravel aquifers sampled by the Minnesota Department of Health, the Minnesota Pollution Control Agency, the U.S. Geological Survey, and the Wisconsin Department of Natural Resources in the study area. 
Table 6.--Frequencies of detection, numbers of wells sampled, concentration ranges and median concentrations of target volatile organic compounds in ground-water samples analyzed by the Minnesota Department of Health, Minnesota Pollution Control Agency, U.S. Geological Survey, and the Wisconsin Department of Natural Resources in the study area, Minnesota and Wisconsin

[First number refers to samples from sand and gravel aquifers, number in parentheses refers to samples from bedrock aquifers; all concentrations in micrograms per liter]

\begin{tabular}{|c|c|c|c|c|}
\hline Volatile organic compound & $\begin{array}{l}\text { Percent of wells } \\
\text { with detection }\end{array}$ & $\begin{array}{l}\text { Number of wells } \\
\text { sampled }\end{array}$ & Concentration range & Median concentration \\
\hline 1,1-dichloroethane & $0.3(2.3)$ & $328(309)$ & $\begin{array}{l}<0.2-0.59 \\
(<0.2-230)\end{array}$ & $<0.2(<0.2)$ \\
\hline 1,2-dichloroethane & $1.5(0.3)$ & $333(328)$ & $\begin{array}{l}<0.2-27 \\
(<0.2-0.6)\end{array}$ & $<0.2(<0.2)$ \\
\hline 1,1,1-trichloroethane & $1.2(1.3)$ & $323(328)$ & $\begin{array}{l}<0.2-5.7 \\
(<0.2-140)\end{array}$ & $<0.2(<0.2)$ \\
\hline Trichloroethene & $3.6(4.6)$ & $333(328)$ & $\begin{array}{l}<0.1-7,200 \\
(<0.1-22)\end{array}$ & $<0.1(<0.2)$ \\
\hline Tetrachloroethene & $1.9(1.2)$ & $321(325)$ & $\begin{array}{l}<0.2-8.6 \\
(<0.2-1.6)\end{array}$ & $<0.2(<0.2)$ \\
\hline Benzene & $3.0(0.92)$ & $333(327)$ & $\begin{array}{l}<0.1-78 \\
(<0.1-1.0)\end{array}$ & $<0.5(<0.5)$ \\
\hline Ethylbenzene & $0.91(0.31)$ & $329(326)$ & $\begin{array}{l}<0.1-8.5 \\
(<0.2-0.7)\end{array}$ & $<0.5(<0.5)$ \\
\hline Toluene & $2.2(2.9)$ & $181(205)$ & $\begin{array}{c}<0.2-2.3 \\
(<0.1-3.8)\end{array}$ & $<0.5(<0.2)$ \\
\hline Meta+para-xylene & $0.48(2.4)$ & $208(209)$ & $\begin{array}{c}<0.2-1.2 \\
(<0.2-0.6)\end{array}$ & $<0.2(<0.2)$ \\
\hline Ortho-xylene & $0.42(1.3)$ & $241(225)$ & $\begin{array}{l}<0.2-0.8 \\
(<0.1-1.0)\end{array}$ & $<0.2(<0.2)$ \\
\hline
\end{tabular}

completed in sand and gravel aquifers (table 6). Less than one percent of the samples from wells completed in sand and gravel aquifers had concentrations of tetrachloroethene and 1,2-dichloroethane exceeding the MCL's of $5 \mu \mathrm{g} / \mathrm{L}$ for those compounds.

Relatively shallow ground water is more susceptible to contamination by VOC's because those compounds are typically introduced into aquifer systems by spills at or near the land surface. Boxplots of the depths of wells producing water with and without detectable concentrations of the target VOC's (fig. 11) indicate that wells producing water with detectable concentrations of those compounds tended to be shallower than wells producing water without detectable concentrations of those compounds. The median depth of wells (not including samples collected by MDH, which are usually mixtures of water from multiple-well systems) yielding water with detectable concentrations of at least one of the target VOC's from sand and gravel aquifers was 55 feet below land surface, whereas the median depth of wells producing water with no detectable concentrations of the target VOC's was 80 feet (fig. 11). Although the boxplots of well depths indicate a difference in the depths of sand and gravel aquifer wells producing water with or without detectable concentrations of the target VOC's, the parametric T- test and the nonparametric Mann-Whitney test did not indicate a significant difference (at a confidence level of 95 percent) in well depths between those two groups.

\section{Bedrock Aquifers}

At least one of the target VOC's was detected in water samples from 69 of 536 wells completed in bedrock aquifers sampled by Federal, State, and local agencies for those compounds (fig. 12). As in the case of sand and gravel aquifers, the target VOC's were most commonly detected in wells completed in bedrock aquifers in the vicinity of registered VOC emission sites, dumps, or landfills (figs. 6, 7a, 7b, and 12). Although water in bedrock aquifers is theoretically less 


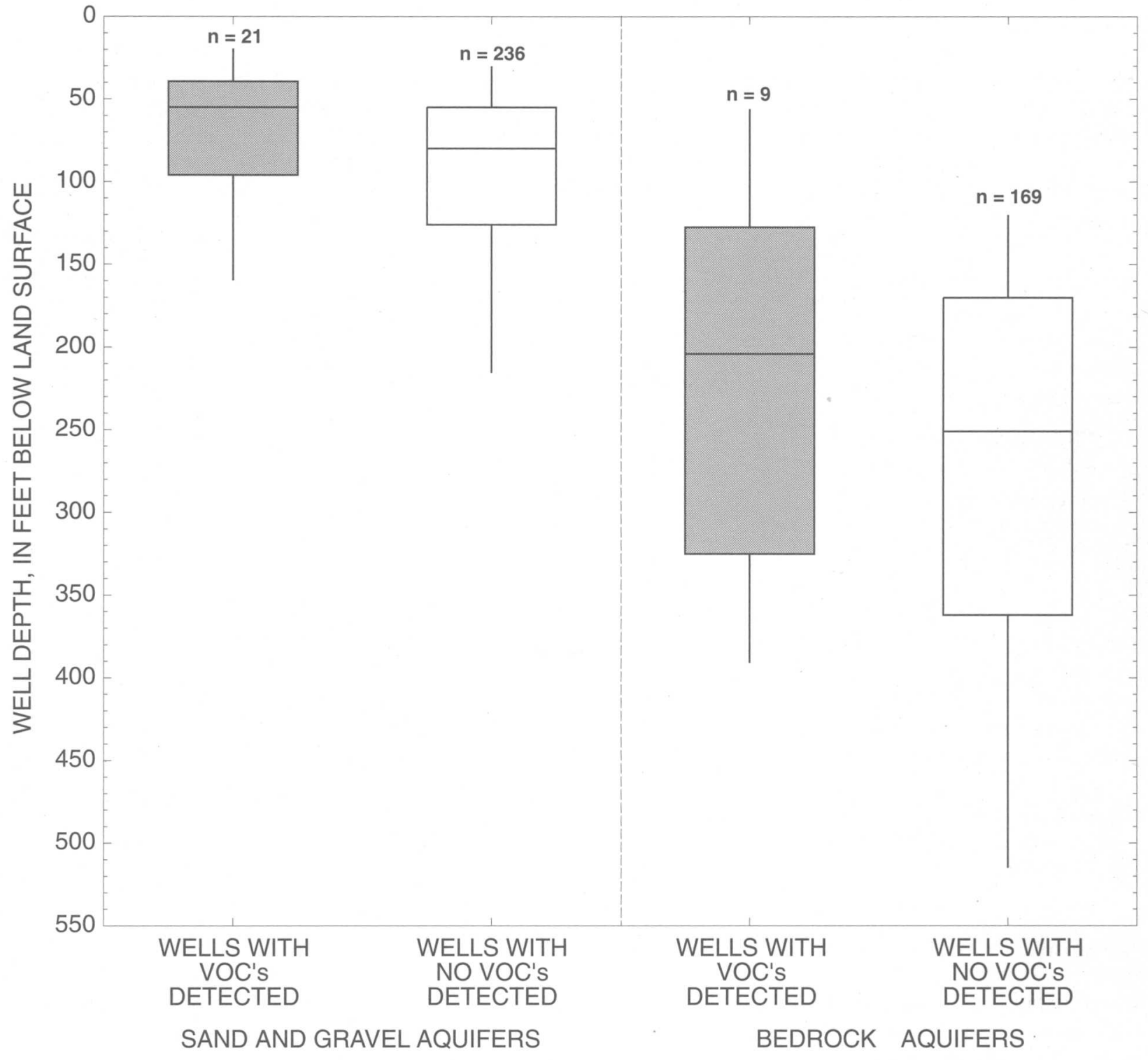

\section{EXPLANATION}

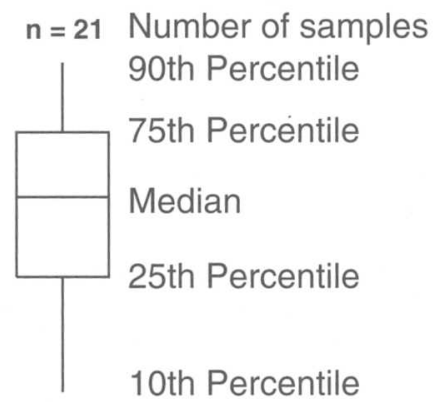

Figure 11.--Boxplots of the relations between well depths and target volatile organic compound (VOC) detections in water samples collected by the Minnesota Department of Health, the Minnesota Pollution Control Agency, the U.S. Geological Survey, and the Wisconsin Department of Natural Resources from sand and gravel and bedrock aquifers in the study area. 
susceptible to contamination than water in surficial sand and gravel aquifers because of the greater depths from land surface, the frequencies of detection of most of the target VOC's were not markedly different than those in water from sand and gravel aquifers (figs. 10, 13; table 6). Detected concentrations of the target VOC's were generally lower, however, in water samples from bedrock aquifers than in samples from sand and gravel aquifers. Only one of the ten target VOC's was detected in concentrations exceeding an MCL in water from wells completed in bedrock aquifers, whereas detected concentrations of four of those compounds exceeded MCL's in water from wells completed in sand and gravel aquifers.

Trichloroethene, detected in water from 15 (4.6 percent) of 328 wells sampled for that compound, was the most-frequently detected target VOC in water from wells completed in bedrock aquifers in the study area (fig. 13, table 6). Water samples from 4 of those wells (1.2 percent) exceeded the MCL of $5 \mu \mathrm{g} / \mathrm{L}$ for trichloroethene (fig. 13). Toluene was the second most commonly detected target VOC (detected in 6 of 205 , or 2.9 percent) in water samples from wells completed in bedrock aquifers in the study area. Meta+para-xylene, a constituent in high-octane gasoline and in exhaust from combustion of that fuel was detected in 5 of 209 water samples ( 2.4 percent) from bedrock wells. Less than two percent of the sampled wells completed in bedrock aquifers produced water with detectable concentrations of the remaining target VOC's (table 6).

As with sand and gravel aquifers, the bedrock-aquifer wells yielding water with detectable concentrations of the target VOC's tended to be shallower (median depth $204 \mathrm{ft}$ ) than wells producing water with no detectable concentrations of those compounds (median depth 251 $\mathrm{ft}$,) (fig. 11). Although the boxplots in figure 11 indicate general differences in the depths of bedrock-aquifer wells producing water with and without detectable concentrations of the target VOC's, the parametric T-test and the nonparametric Mann-Whitney test did not indicate a significant difference in well depths between those two groups at a confidence level of 95 percent.

\section{Trihalomethane Compounds in Surface and Ground Water}

Trihalomethane compounds (THM's) are VOC's composed of a central carbon atom to which three of any of the halogen atoms--chlorine, bromine, or fluorine, are bonded. THM's have been primarily associated with chlorination of waters containing organic compounds (Rook, 1974, International Agency for Research on Cancer, 1991). The THM's analyzed in surface- and ground-water samples by the USGS, MDH, MPCA,
MCES, and WDNR in the study area include: chloroform $\left(\mathrm{CHCl}_{3}\right)$, bromodichloromethane $\left(\mathrm{CHBrCl}_{2}\right)$, chlorodibromomethane $\left(\mathrm{CHClBr}_{2}\right)$, bromoform $\left(\mathrm{CHBr}_{3}\right)$, and fluorodichloromethane $\left(\mathrm{CHFICl}_{2}\right)$. Of these compounds, only chloroform has been listed as a suspected carcinogen by the USEPA (U.S. Environmental Protection Agency, 1981). Because of this carcinogenic risk, an MCL of $100 \mu \mathrm{g} / \mathrm{L}$, which is not compoundspecific, has been established for THM's (U.S. Environmental Protection Agency, 1994a),

THM's were the most commonly detected VOC's in surface- and ground-water samples collected by the $\mathrm{MDH}$. Most of the water samples analyzed by that agency were chlorinated, which probably contributed to the relatively high incidence of detectable concentrations of THM's in those samples. THM's detected in chlorinated surface and ground water ranged in chlorine content from the most chlorinated, chloroform, to the least chlorinated, bromoform.

Chloroform, the most chlorinated THM, was the most commonly detected THM in chlorinated surface-water samples (fig. 14). Of the 46 samples of chlorinated surface water, used by the cities of Minneapolis, St. Paul, and St. Cloud as their primary source of water supply, 100 percent had detectable concentrations of chloroform (fig. 14). Concentrations of chloroform in those samples ranged from 0.2 to $85 \mu \mathrm{g} / \mathrm{L}$. None of the unchlorinated surface-water samples from the Minnesota and Mississippi Rivers analyzed by MCES contained detectable concentrations of chloroform (fig. 14).

Ground-water samples with detectable concentrations of THM's were commonly from wells located along streams and rivers in the study area (figs. 15, 16). Increased frequencies of detection of trihalomethane VOC's in ground water (particularly after chlorination) may be due to mixing of ground water in alluvial aquifers and hydraulically connected bedrock aquifers with relatively organic rich surface water. Thirty-five percent of the 43 chlorinated water samples from wells completed in sand and gravel aquifers sampled by the MDH produced water with detectable concentrations of chloroform (fig. 17), with chloroform concentrations in those samples ranging from 0.2 to $31 \mu \mathrm{g} / \mathrm{L}$. In comparison, 3.8 percent of 290 unchlorinated water samples from sand and gravel aquifer wells collected by other agencies had detectable concentrations of chloroform (fig. 17). Forty percent of chlorinated water samples analyzed by MDH from 108 wells completed in 


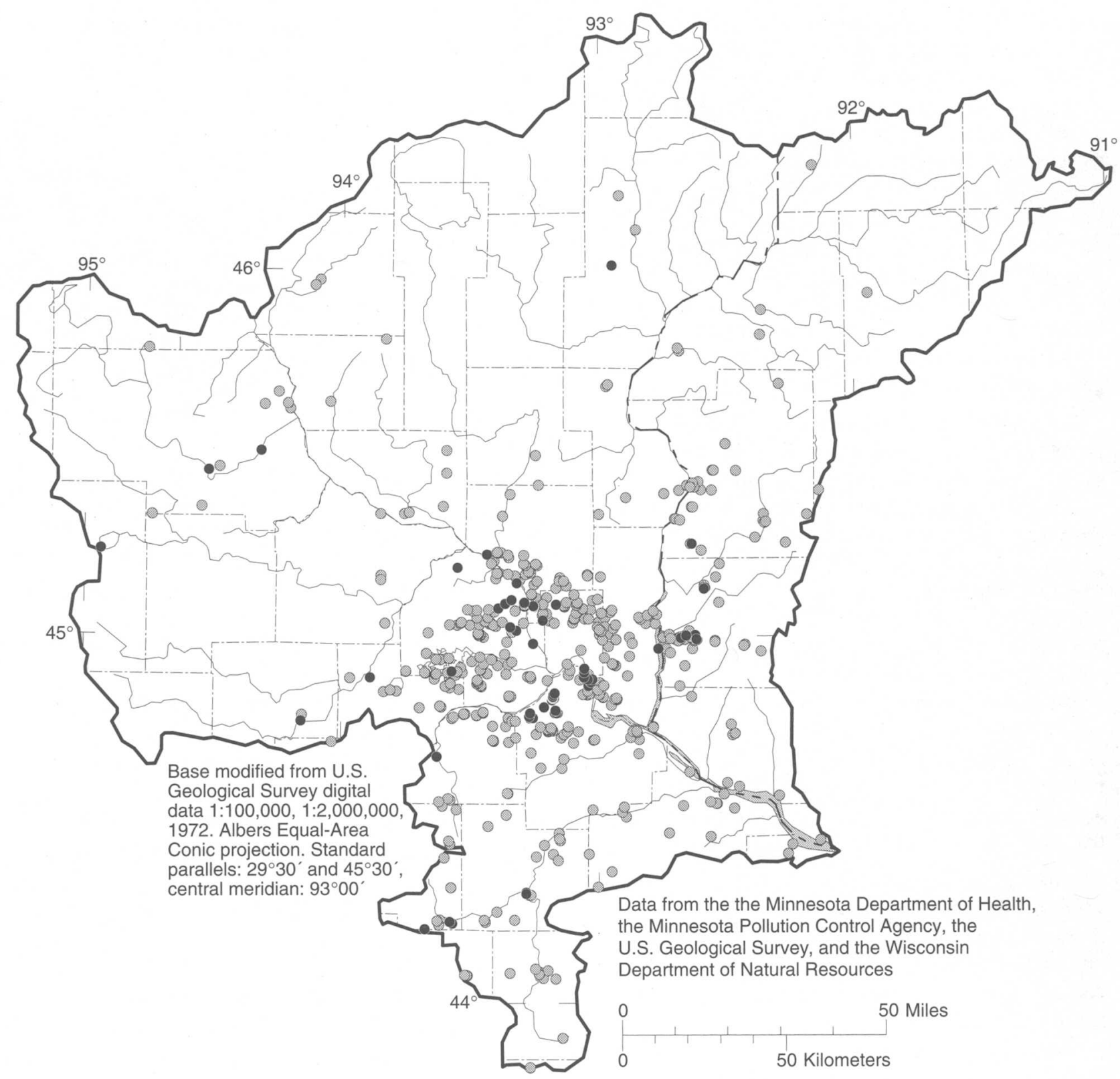

EXPLANATION

- Well sampled for VOC's with none detected

- Well sampled for VOC's with detection of one or more VOC compound

Figure 12.--Locations of sampled wells and locations of wells with detections of target volatile organic compounds (VOC's) for bedrock aquifers in the study area. 


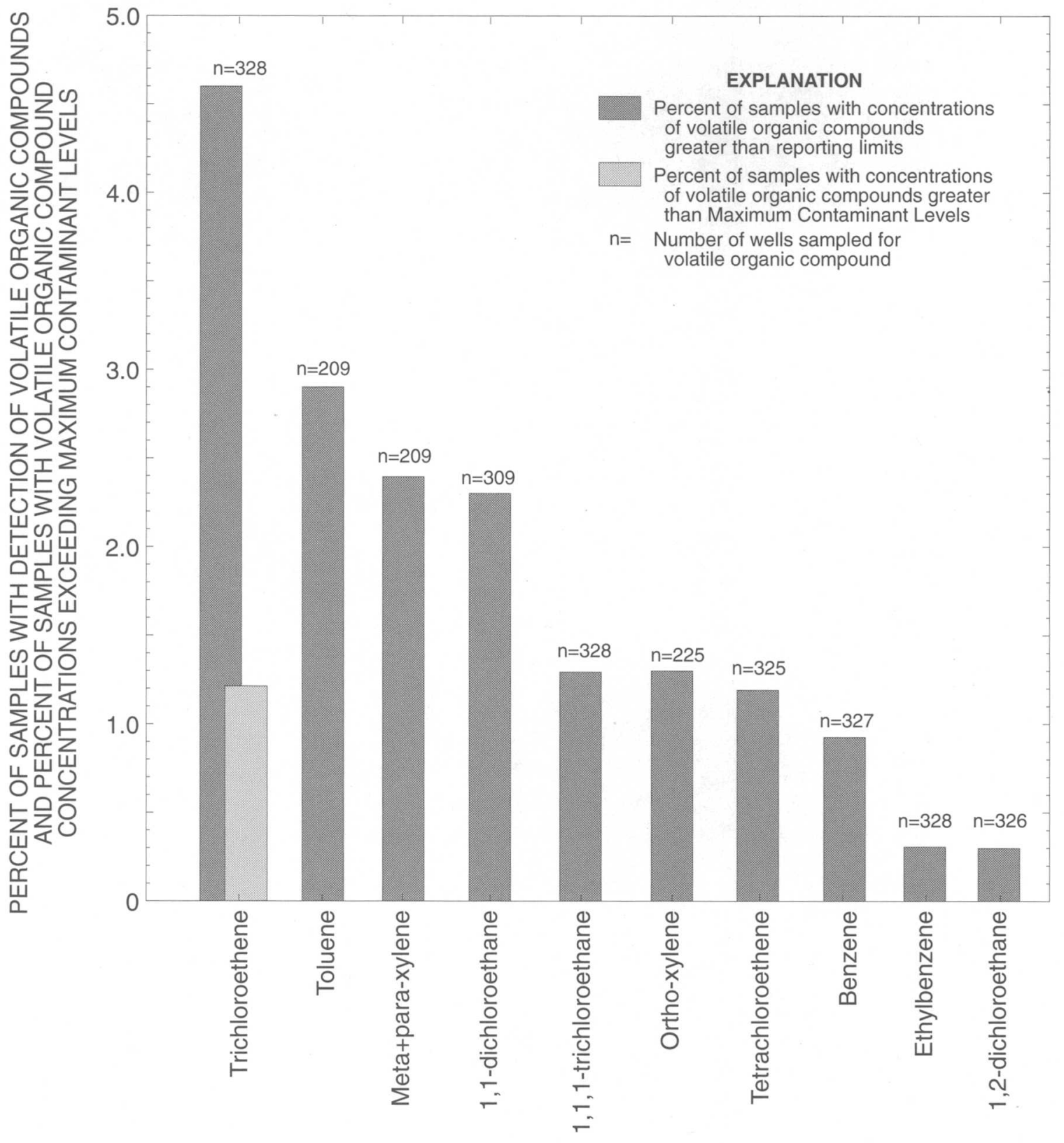

VOLATILE ORGANIC COMPOUND

Figure 13.--Percentages of detection of target volatile organic compounds and percentages of samples with concentrations exceeding Maximum Contaminant Levels for those compounds in water samples from wells completed in bedrock aquifers sampled by the Minnesota Department of Health, the Minnesota Pollution Control Agency, the U.S. Geological Survey, and the Wisconsin Department of Natural Resources in the study area. 


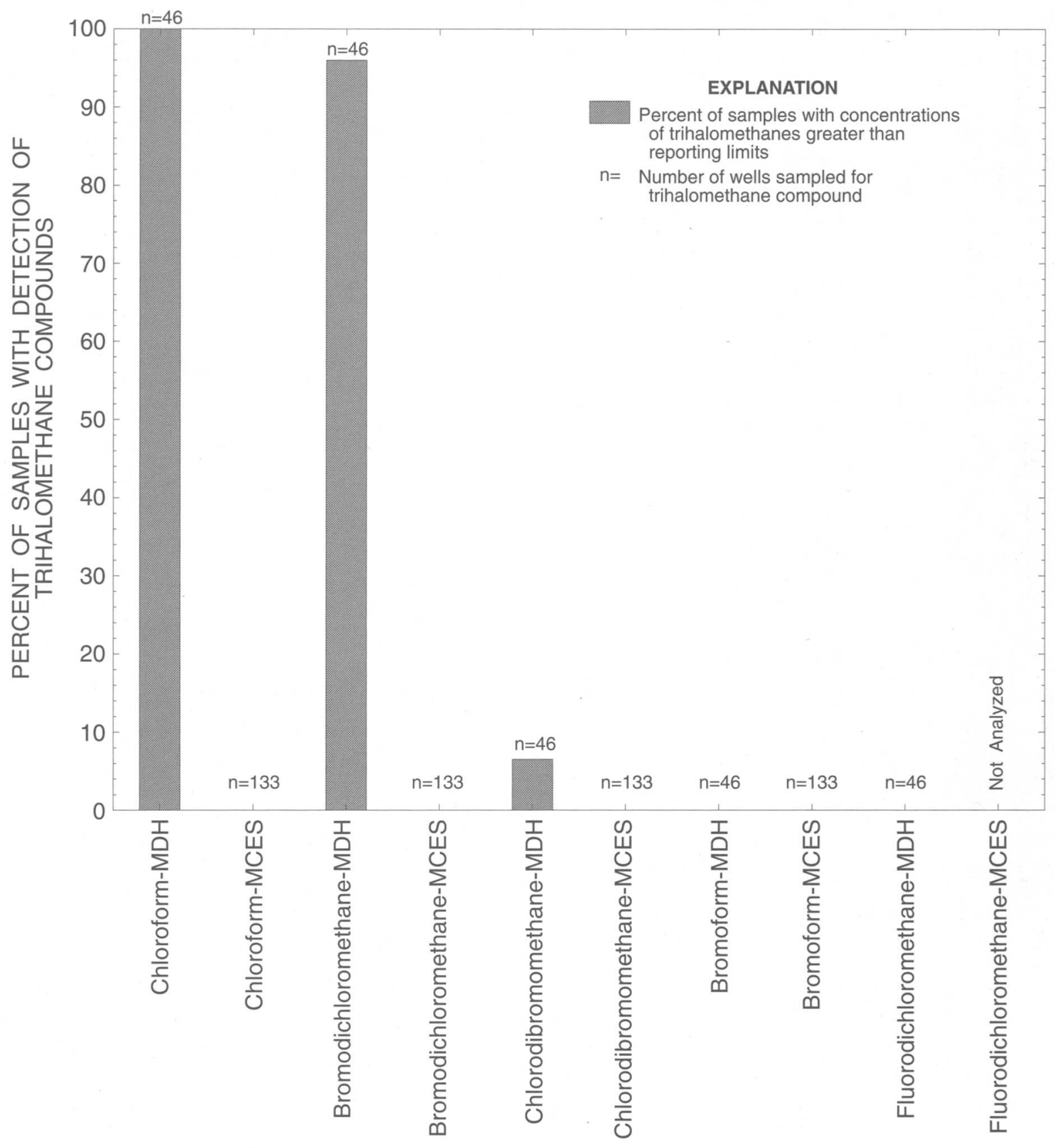

TRIHALOMETHANE COMPOUNDS, BY AGENCY GROUP

Figure 14.--Percentage of detection of analyzed trihalomethane compounds in water from surface-water sites sampled by the Minnesota Department of Health (MDH), and the Metropolitan Council Environmental Services (MCES) in the study area. 
bedrock aquifers produced finished water with detectable concentrations of chloroform (fig. 18), with chloroform concentrations in those samples ranging from 0.1 to $12 \mu \mathrm{g} / \mathrm{L}$. Less than one percent of 211 unchlorinated ground-water samples from wells completed in bedrock aquifers collected by other agencies contained detectable concentrations of chloroform (fig. 18). Chloroform concentrations in unchlorinated ground-water samples collected from wells completed in both types of aquifers ranged from 0.2 to $3.2 \mu \mathrm{g} / \mathrm{L}$. Frequencies of detection and detected concentrations of chloroform in those "unchlorinated" water samples may have been increased in some samples by chlorinators connected to domestic wells sampled by the MPCA (Thomas P. Clark, Minnesota Pollution Control Agency, oral commun., 1995).

Bromodichloromethane, containing one less chlorine atom and one more bromine atom than chloroform, was the second most commonly detected THM in chlorinated surface-water samples collected by the $\mathrm{MDH}$, being detected in approximately 96 percent of those 46 samples (fig. 14), with detected concentrations ranging from 0.4 to $10 \mu \mathrm{g} / \mathrm{L}$. Bromodichloromethane was detected in 19 percent of 43 systems producing chlorinated water from sand and gravel aquifers (fig. 17), with detected concentrations ranging from 0.2 to $7.2 \mu \mathrm{g} / \mathrm{L}$. Twenty-nine percent of the 108 systems producing chlorinated water from wells completed in bedrock aquifers produced water with detectable concentrations of bromodichloromethane (fig. 18), with detected concentrations ranging from 0.2 to $6.2 \mu \mathrm{g} / \mathrm{L}$. Of the 511 unchlorinated wells sampled by other agencies, none yielded water with detectable concentrations of bromodichloromethane (figs. 17, 18).

Chlorodibromomethane, which contains one less chlorine atom and one more bromine atom than bromodichloromethane, was detected in fewer chlorinated water samples than bromodichloromethane. Of the 46 chlorinated surfacewater samples analyzed by the MDH from Minneapolis, St. Paul, and St. Cloud, 6.5 percent contained detectable concentrations of chlorodibromomethane (fig. 14). Nineteen percent of 43 water systems producing chlorinated water from sand and gravel aquifers produced water with detectable concentrations of chlorodibromomethane (fig. 17), with concentrations of that compound ranging from 0.9 to $2.0 \mu \mathrm{g} / \mathrm{L}$. None of the unchlorinated water samples from 294 wells completed in sand and gravel aquifers, which were analyzed by other agencies, had detectable concentrations of chlorodibromomethane (fig. 17). Thirteen percent of the chlorinated water samples from 108 water systems withdrawing water from bedrock aquifers sampled by the MDH had detectable concentrations of chlorodibromomethane (fig. 18), with detected concentrations ranging from 0.6 to $4.6 \mu \mathrm{g} / \mathrm{L}$. Only one of the unchlorinated water samples from 213 wells completed in bedrock aquifers sampled by other agencies had a detectable concentration of chlorodibromomethane (figs. 17, 18).

The least chlorinated THM, bromoform, which contains three bromine atoms and no chlorine atoms, was not detected in any of the chlorinated or unchlorinated surfacewater samples analyzed by the MDH and the MWCS (fig. 14). Bromoform was also not detected in chlorinated water from the 43 public-supply systems withdrawing water from sand and gravel aquifers sampled by the MDH or in water from the 501 wells completed in sand and gravel and bedrock aquifers sampled by other agencies (fig. 17). Bromoform was detected in only one of the chlorinated water samples analyzed by the $\mathrm{MDH}$ from 108 systems withdrawing water from bedrock aquifers (fig. 18).

Fluorodichloromethane, the only analyzed fluoridated THM, was analyzed in 46 surface-water samples collected by the MDH and was not detected in any of those chlorinated water samples (fig. 14).

Fluorodichloromethane concentrations were analyzed in ground-water samples collected by the MDH and the MPCA-GWMAP. None of the 149 samples collected from wells completed in sand and gravel or bedrock aquifers by those agencies had detectable concentrations of fluorodichloromethane (figs. 17, 18).

The relatively high incidences of detection of the more heavily chlorinated THM's, particularly in chlorinated water samples analyzed by the $\mathrm{MDH}$, indicate that chlorination of surface and ground water can produce relatively high incidences of detectable concentrations of THM's. Frequencies of detection and detected concentrations of THM's were higher in chlorinated surface-water samples, which typically have higher organic-carbon concentrations (a necessary precursor for THM formation) than ground water. The infrequent detection of THM's in unchlorinated surface- and groundwater samples indicates that these compounds are not naturally present in currently detectable concentrations in surface and ground water in the study area. 


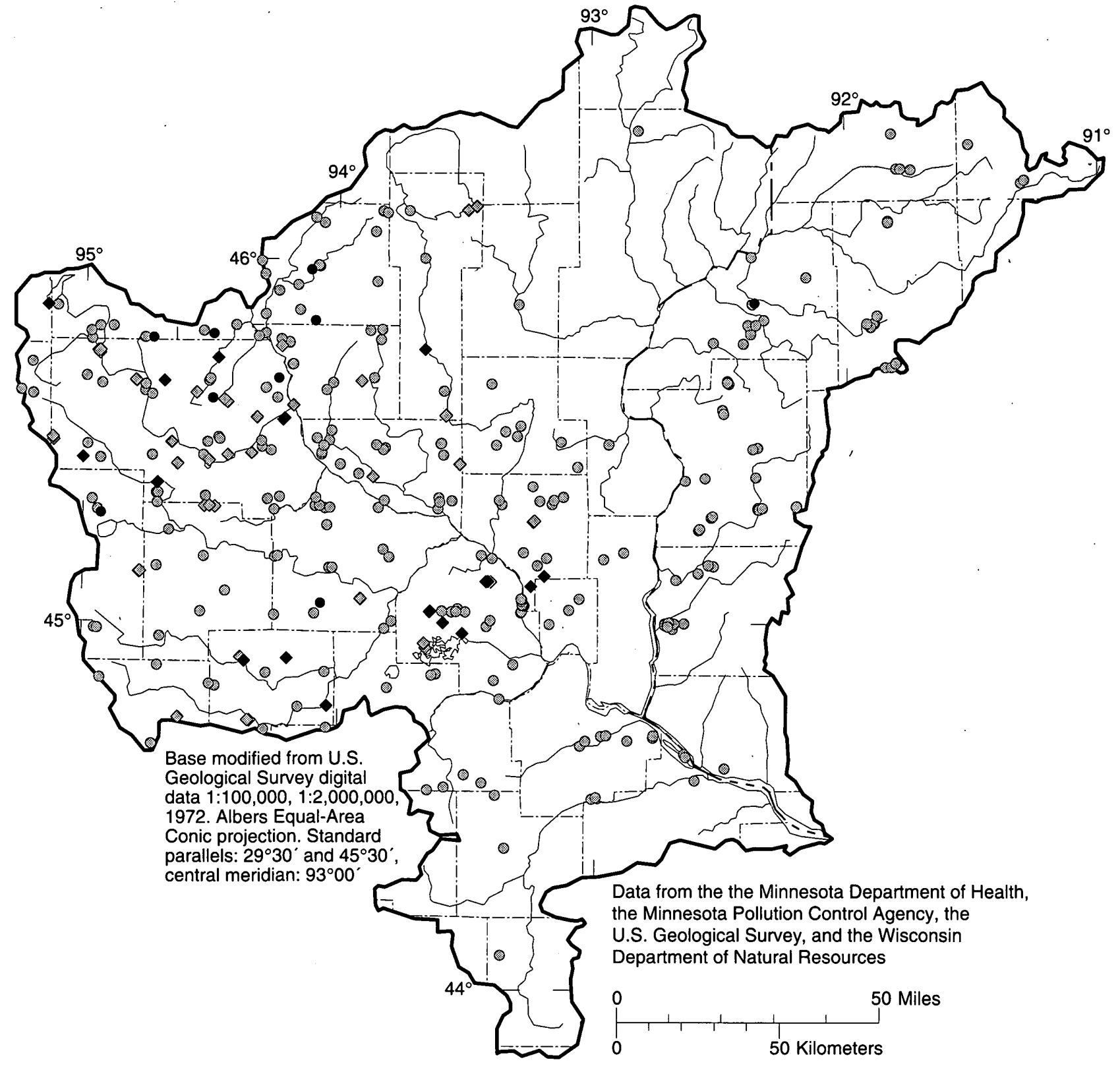

EXPLANATION

- Well sampled for trihalomethane compounds with none detected

- Well sampled with detection of one or more trihalomethane compound $\diamond$ Well sampled by Minnesota Department of Health for trihalomethane compounds with none detected

- Well sampled by Minnesota Department of Health with detection of one or more trihalomethane compound

Figure 15.--Locations of sampled wells and locations of wells with detections of trihalomethane compounds for sand and gravel aquifers in the study area. 


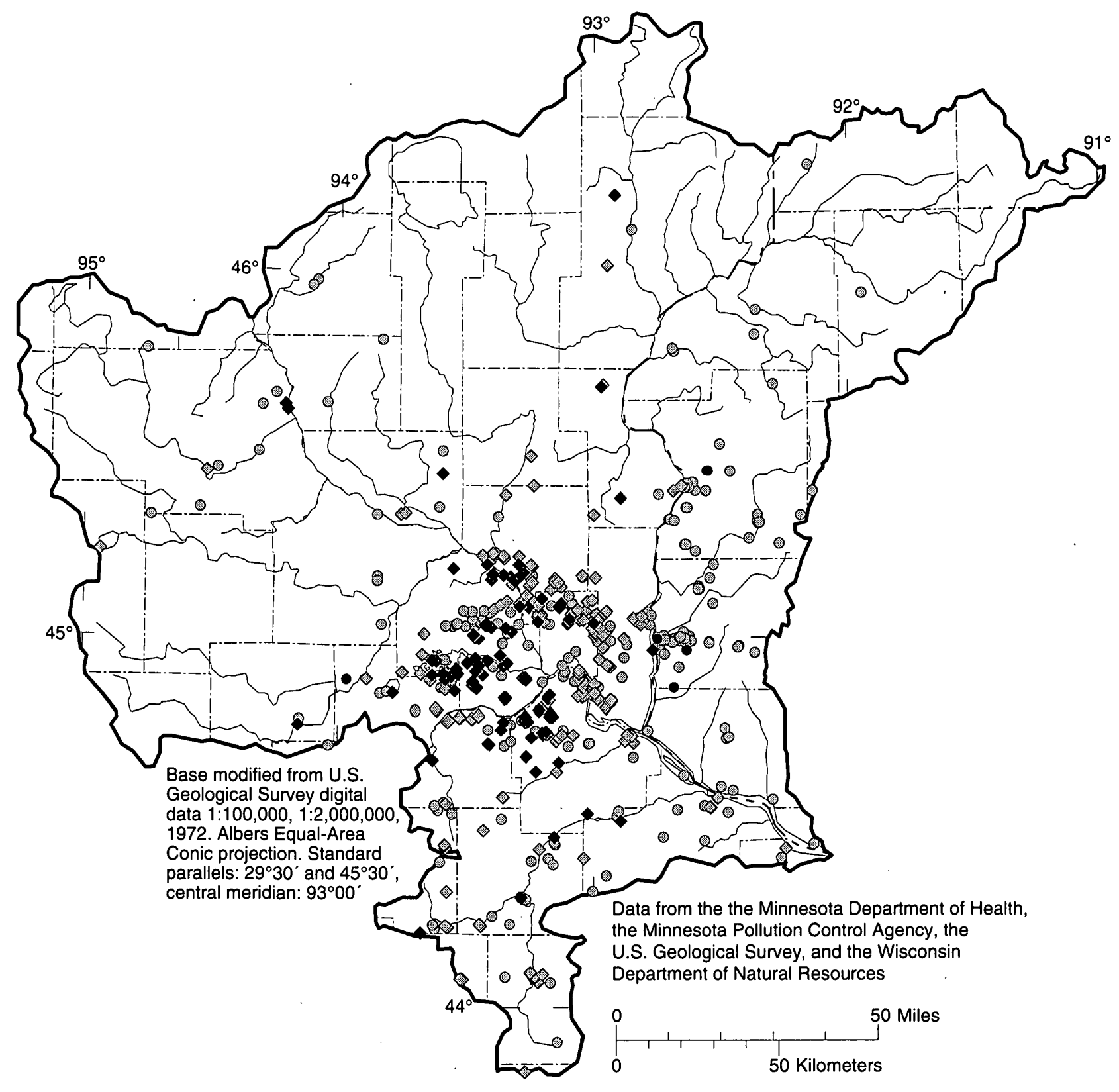

\section{EXPLANATION}

- Well sampled for trihalomethane compounds with none detected

- Well sampled with detection of one or more trihalomethane compound $\diamond$ Well sampled by Minnesota Department of Health for trihalomethane compounds with none detected

- Well sampled with detection of one or more trihalomethane compound

Figure 16.--Locations of sampled wells and locations of wells with detections of trihalomethane compounds for bedrock aquifers in the study area. 


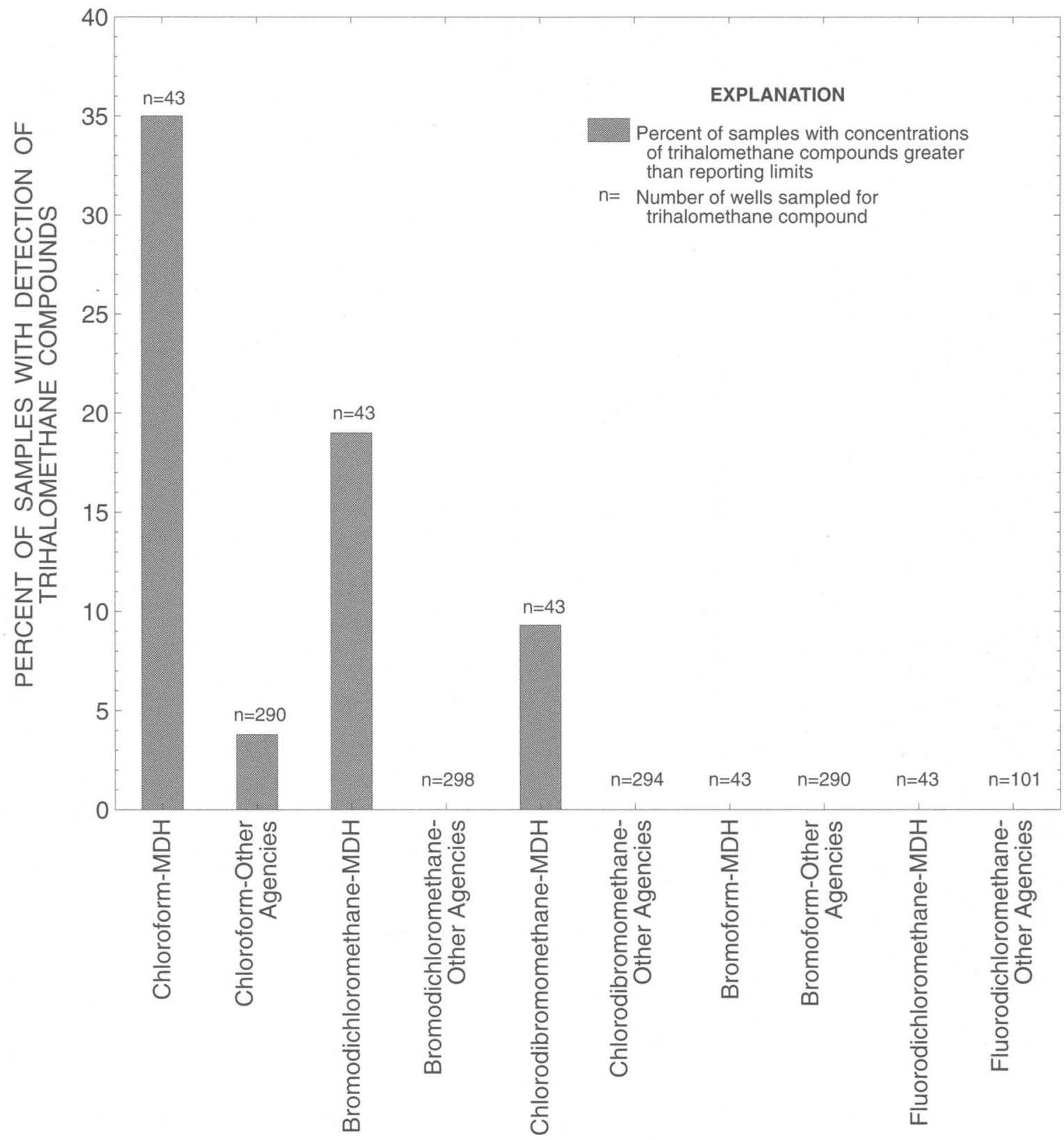

TRIHALOMETHANE COMPOUNDS, BY AGENCY GROUP

Figure 17.--Percentages of detection of analyzed trihalomethane compounds in water from wells completed in sand and gravel aquifers sampled by the Minnesota Department of Health (MDH), the Minnesota Pollution Control Agency, the U.S. Geological Survey, and the Wisconsin Department of Natural Resources in the study area. 


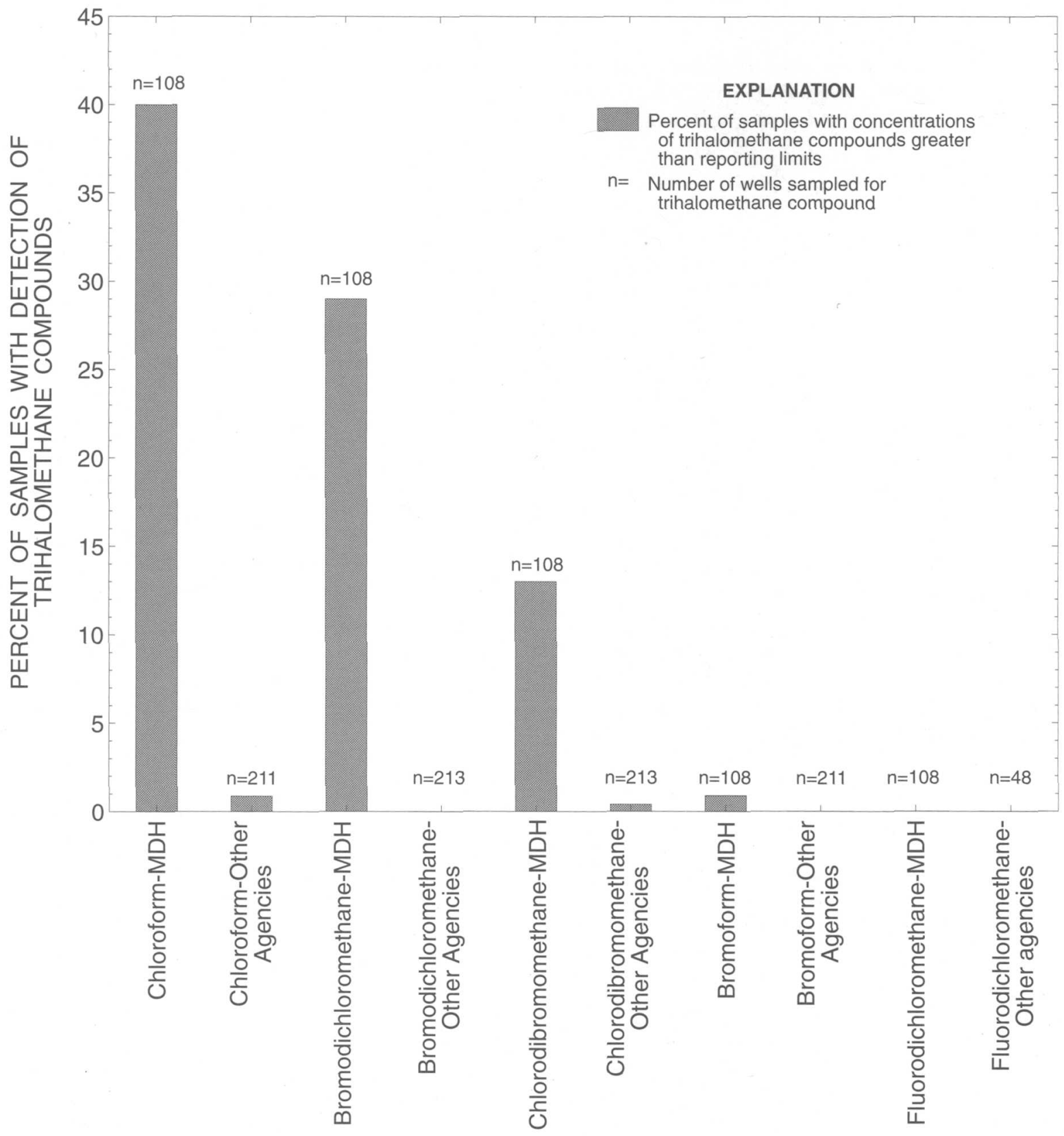

TRIHALOMETHANE COMPOUNDS, BY AGENCY GROUP

Figure 18.--Percentages of detection of analyzed trihalomethane compounds in water from wells completed in bedrock aquifers sampled by the Minnesota Department of Health (MDH), the Minnesota Pollution Control Agency, the U.S. Geological

Survey, and the Wisconsin Department of Natural Resources in the study area. 


\section{Summary and Conclusions}

As part of a retrospective analysis of water-quality data for the Upper Mississippi River Basin study unit of the National Water-Quality Assessment Program, the U.S. Geological Survey compiled and summarized analyses of concentrations of volatile organic compounds in surface and ground water from waterquality data bases maintained by Federal, State, and local agencies. The study area described in this report encompasses an area of about $19,500 \mathrm{mi}^{2}$. The study area includes the St. Croix River Basin and the Upper Mississippi River Basin from Lake Pepin upstream to sampling stations on the Minnesota and Mississippi Rivers where long-term water-quality data are available. The area includes rich agricultural lands, forests, wetlands, prairies, and the Twin Cities metropolitan area, consisting of the cities of Minneapolis and St. Paul and the seven surrounding counties.

VOC's in surface and ground water are an issue of concern due to potential carcinogenic effects of longterm exposure to relatively small concentrations of these compounds in drinking water. VOC's are carbon-based compounds, generally composed of relatively small molecules that readily vaporize at standard temperature and pressure. VOC's may be discharged to the atmosphere, land, and water at thousands of sites in the study area where they are stored, used, or disposed of, including factories, auto fueling and service stations, airports, refineries, dry cleaners, printing plants, landfills, salvage yards, and dumps.

Water-quality data sources used for this retrospective analysis include widely distributed networks sampled in the study area by the U.S. Geological Survey, the Minnesota Department of Health, the Minnesota Pollution Control Agency, the Wisconsin Department of Natural Resources, the Metropolitan Council Environmental Services, and the City of Minneapolis. Ground-waterquality data from wells installed at known VOC spill or disposal sites were not combined with the data from regionally distributed sampling networks, because VOC concentrations at those sites are well-documented and this report focuses on the quality of water on a regional, rather than a local scale.

Examination of water-quality data from widely distributed networks of river sampling sites and wells in the study area led to the following conclusions: 1) trace amounts of chlorinated VOC's such as trichloroethane, a commonly used solvent, were detected in waters of the Mississippi, Minnesota, and Vermillion Rivers; 2) benzene, ethylbenzene, toluene, and meta-xylene were detected in waters sampled from the lakes used to convey and store Mississippi River water to St. Paul, Minnesota;
3) the target VOC's were detected in less than five percent of water samples at relatively low concentrations, generally near detection limits from 1 to 5 micrograms per liter; 4) VOC's were generally detected at similar frequencies, but at higher concentrations, in water samples from wells completed in sand and gravel aquifers than in water samples from wells completed in bedrock aquifers; 5) VOC's were most commonly detected in ground water near identifiable VOC emission sites such as dumps, landfills, and major industries; 6) trichloroethene, a commonly used degreasing agent for dry cleaning, metal cleaning and cleaning septic lines, was the most frequently detected target VOC in ground water sampled from wells completed in both sand and gravel and bedrock aquifers; 7) wells producing water with detectable concentrations of the target VOC's tended to be shallower than wells producing water with no detectable concentrations of those compounds, but those differences were not statistically significant at a 95 percent confidence level; and 8) chlorination of surface and ground water substantially increased the frequency of detection of trihalomethane compounds, including chloroform, bromodichloromethane, and chlorodibromomethane.

The relatively low frequencies of detection of the target VOC's indicate that although there are thousands of sites which potentially emit these compounds to water and to the atmosphere in the study area, these VOC's have not had a widespread, measurable effect on the quality of surface and ground water in the area. Frequencies of detection of these compounds in water from wells cited in the immediate vicinity of VOC emission sites, such as major industrial sites, leaking underground storage tanks, landfills, and dumps can be much higher than in water from wells in widely distributed networks. Ground-water-quality sampling conducted during the 1980's throughout the State of Minnesota by the Minnesota Department of Health, indicated that water from wells in the vicinity of VOC point sources, had frequencies of detection as high as 33 percent for those compounds.

THM's, which can be formed by the chlorination of waters containing naturally occurring organic compounds, were the most frequently detected VOC's in chlorinated water samples analyzed in the study area. Relatively high frequencies of detection of the more heavily chlorinated THM's, particularly chloroform, in chlorinated water samples analyzed by the MDH indicate that chlorination of surface and ground water produces relatively high frequencies of detection of chlorine rich THM's (up to 100 percent of surface-water samples and up to 40 percent of ground-water samples). The relatively low frequencies of detection of THM's in unchlorinated surface- and ground-water samples (less 
than 5 percent, some of which may be attributable to chlorination systems on wells) indicate that these compounds are not naturally present in surface and ground water in the study area.

\section{References Cited}

Adolphson, D.G., Ruhl, J.F., and Wolf, R.J., 1981, Designation of principal water-supply aquifers in Minnesota: U.S. Geological Survey WaterResources Investigations Report 81-51, 19 p.

Agency for Toxic Substances and Disease Registry, 1990, Hexachlorobenzene: Agency for Toxic Substances and Disease Registry Public Health Statement, Atlanta, Georgia, 3 p.

Anderson, H.W., Jr., 1986, Hydrogeologic and waterquality characteristics of crystalline-rock aquifers of Archean and Proterozoic Age, Minnesota: U.S. Geological Survey, Water-Resources Investigations Report 86-4033, 3 sheets.

Anderson, J.R., Hardy, E.E., Roach, J.T., and Witmer, R.E., 1976, A land use and land cover classification system for use with remote sensor data: U.S. Geological Survey, Professional Paper $964,28 \mathrm{p}$.

Andrews, W.J., Trotta, L.C., and Schoenberg, M.E., in press, Water-level declines from 1980-90 in major aquifers in the Twin Cities area in Proceedings of the Symposium on Water Management in Urban Areas, American Water Resources Association, 31st Annual Conference, November 5-9, 1995 , Houston, TX.

Baker, D.G., Nelson, W.W., and Kuehnast, E.L., 1979, Climate of Minnesota, Part XII--the hydrologic cycle and soil water: University of Minnesota, Agricultural Experiment Station, Technical Bulletin 322, 23 p.

Baker, D.G., Kuehnast, E.L., and Zandlo, J.A., 1985, Climate of Minnesota,.Part XV--normal temperature (1951-1980) and their application: University of Minnesota, Agricultural Experiment Station, AD-SB-2777-1985, $66 \mathrm{p}$.

Brown, B.A., 1988, Bedrock geology of Wisconsin, regional map series, west-central sheet: Wisconsin Geological and Natural History Survey Map 88-7, 1 sheet.
Ciccioli, P., 1993, VOCs and air pollution, in Bloemen, H.J., and Burn, J., eds., Volatile organic compounds in the environment (1st ed.): Chapman and Hall, Glasgow, United Kingdom, 290 p.

Delin, G.N., and Woodward, D.G., 1982, Hydrogeologic setting and the potentiometric surfaces of the regional aquifers of the Hollandale Embayment, southeastern Minnesota, 1970-80: U.S. Geological Survey Water-Supply Paper 2219, $56 \mathrm{p}$.

Friedman, L.C., and Erdmann, D.E., 1982, Quality assurance practices for the chemical and biological analyses of water and fluvial sediments: U.S. Geological Survey Techniques of WaterResources Investigations of the U.S. Geological Survey, book 5, chapter A6, $181 \mathrm{p}$.

HDR Engineering, Inc., 1992, City of Minneapolis storm water NPDES Part II - monitoring and modeling results: HDR Engineering, Inc., Minneapolis, Minnesota, variously-paged.

Helsel, D.R., and Hirsh, R.M., 1992, Statistical methods in water resources, Studies in Environmental Science 49: Elsevier, 522 p.

International Agency for Research on Cancer, 1991, Monographs on the evaluation of carcinogenic risks to humans, v. 52, Chlorinated drinking-water; chlorination by-products; some other halogenated compounds; cobalt and cobalt compounds: International Agency for Research on Cancer, Lyon, France.

Kanivetsky, R., 1978, Hydrogeologic map of Minnesota, bedrock hydrogeology: Minnesota Geological Survey Map Series S-2, scale 1:500,000, 1 sheet.

Kliest, J.J.G., 1993, VOC's and soil pollution, in Bloemen, H.J., and Burn, J., eds., Volatile organic compounds in the environment (1st ed.): Chapman and Hall, Glasgow, United Kingdom, 290 p.

Kotzias, D. and Sparta, C., 1993, VOC's and water pollution, in Bloemen, H.J., and Burn, J., eds., Volatile organic compounds in the environment (1st ed.): Chapman and Hall, Glasgow, United Kingdom, 290 p. 
Leete, J.H., 1991, Ground water quality and management in Minnesota: Journal of the Minnesota Academy of Science, v. 56, no., 1, p. 34-43.

Metropolitan Waste Control Commission, 1994, 1991 River water quality data report: MWCC report number QC-91-274, St. Paul, Minnesota, variously paged.

Minnesota Department of Health, 1985, Volatile organic survey of community water supplies, Report to the Legislative Commission on Minnesota Resources: Minnesota Department of Health, Section of Water Supply and Engineering, Minneapolis, 23 p.

Minnesota Department of Health, 1988, Noncommunity public water supply survey for volatile organic chemicals, Report to the Legislative Commission on Minnesota Resources: Minnesota Department of Health, Section of Water Supply and Engineering, Minneapolis, $21 \mathrm{p}$.

Minnesota Department of Health, 1989, Water supply monitoring near metropolitan solid waste disposal facilities, Report to the Legislative Commission on Minnesota Resources: Minnesota Department of Health, Section of Water Supply and Engineering, Minneapolis, $34 \mathrm{p}$.

Minnesota Department of Health, 1993, MDH Chemical Laboratory Handbook: Minnesota Department of Health, Public Health Laboratory Division, Chemical Laboratory, 32 p.

Minnesota Pollution Control Agency, 1990, Minnesota water quality, water years 1988-1989--the 1990 report to the Congress of the United States, $220 \mathrm{p}$.

Olcott, P.G., 1992, Ground water atlas of the United States, Segment 9; Iowa, Michigan, Minnesota, Wisconsin: U.S. Geological Survey Hydrologic Investigations Atlas 730-J, $31 \mathrm{p}$.

Rook, J.J., 1974, Formation of haloforms during chlorination of natural water: Journal of Water Treatment Examination, v. 23, p. 234.
Rose, D.L., and Schroeder, M.P., 1995, Methods of analysis by the U.S. Geological Survey National Water Quality Laboratory--determination of volatile organic compounds in water by purge and trap capillary gas chromatography/mass spectrometry: U.S. Geological Survey Open-File Report 94-708, 26 p.

Ruhl, J.F., 1987, Hydrogeologic and water-quality characteristics of glacial-drift aquifers in Minnesota: U.S. Geological Survey WaterResources Investigations Report 87-4224, 3 sheets.

Schlotthauer, J, 1994, GWMAP Field Sampling Protocol, Revision 2.0,: Minnesota Pollution Control Agency, $15 \mathrm{p}$.

Trotta, L., and Cotter, R.D., 1973, Depth to bedrock in Wisconsin: University of Wisconsin-Extension Geological and Natural History Survey, 1 sheet, $1: 1,00,000$.

U.S. Environmental Protection Agency, 1981, Second annual report on carcinogens: NTP 81-43

1994a, National primary drinking water standards, U.S. Environmental Protection Agency, EPA 810-F-94-001A, 4 p.

1994b, Drinking water regulations and health advisories, U.S. Environmental Protection Agency, $18 \mathrm{p}$.

1994c, 1992 Toxics Release Inventory, Public Data Release: U.S., Environmental Protection Agency, EPA 745-R-94-001, 372 p.

1995, Drinking water regulations and health advisories, U.S. Environmental Protection Agency, $11 \mathrm{p}$.

U.S. Office of Technology Assessment, 1987, Managing industrial effluents, in Wastes in the marine environment: Office of Technology Assessment, OTA-O-334, p. 178-205.

Verschueren, Karel, 1983, Handbook of environmental data on organic chemicals, New York, N. Y., Van Nostrand Reinhold, 1310 p.

Ware, G.W., ed., 1994, Reviews of Environmental Contamination and Toxicology, Springer-Verlag, v. $140,221 \mathrm{p}$. 
Wershaw, R.L., Fishman, M.J., Grabbe, R.R., and Lowe, L.E., 1987, Methods for the determination of organic substances in water and fluvial sediments: U.S. Geological Survey Techniques of WaterResources Investigations of the United States Geological Survey, book 5, chapter A3, 80 p.

Wood, W.W., 1976, Guidelines for collection and field analysis of ground-water samples for selected unstable constituents: U.S. Geological Survey Techniques of Water-Resources Investigations of the United States Geological Survey, book 5 , chapter A3, $24 \mathrm{p}$.

Woodward, D.G., 1986, Hydrogeologic framework and properties of regional aquifers in the Hollandale Embayment, southeastern Minnesota: U.S. Geological Survey Hydrologic Investigations Atlas HA-677, 2 sheets.

Woodward, D.G., and Anderson, H.W., Jr., 1986, Hydrogeologic and water-quality characteristics of the Cretaceous aquifer in southwestern Minnesota: U.S. Geological Survey Water-Resources Investigations Report 84-4153, 2 sheets. 
ㅇํㄹ

ग

రి : 